\title{
A genome-wide association study in Indian wild rice accessions for resistance to the root-knot nematode Meloidogyne graminicola
}

\author{
Alkesh Hada \\ Indian Agricultural Research Institute \\ Tushar K. Dutta \\ Indian Agricultural Research Institute \\ Nisha Singh \\ National Institute for Plant Biotechnology \\ Vandna Rai \\ National Institute for Plant Biotechnology \\ Nagendra K. Singh \\ National Institute for Plant Biotechnology \\ Uma Rao ( $\sim$ umarao@iari.res.in )
}

Research article

Keywords: GWAS; QTL; SNP; PF-127 medium; NBS-LRR protein; bZIP TF

Posted Date: March 12th, 2020

DOI: https://doi.org/10.21203/rs.3.rs-17007/v1

License: (c) (i) This work is licensed under a Creative Commons Attribution 4.0 International License. Read Full License 


\section{Abstract}

Background: Rice root-knot nematode (RRKN), Meloidogyne graminicola is one of the major biotic constraints in rice-growing countries of Southeast Asia. Host plant resistance is an environmentally-friendly and cost-effective mean to mitigate RRKN damage to rice.

Considering the limited availability of genetic resources in the Asian rice (Oryza sativa) cultivars, exploration of novel sources and genetic basis of RRKN resistance is necessary.

Results: We screened 272 diverse wild rice accessions (O. nivara, O. rufipogon, O. sativa f. spontanea) to identify genotypes resistant to RRKN. We dissected the genetic basis of RRKN resistance using a genome-wide association study with SNPs (single nucleotide polymorphism) genotyped by 50K "OsSNPnks" genic Affymetrix chip. Population structure analysis revealed that these accessions were stratified into three major sub-populations. Overall, 40 resistant accessions (nematode gall number and multiplication factor/MF $<2$ ) were identified, with 17 novel SNPs being significantly associated with phenotypic traits such as number of galls, egg masses, eggs/egg mass and MF per plant. SNPs were localized to the quantitative trait loci (QTL) on chromosome 1, 2, 3, 4, 6, 10 and 11 harboring the candidate genes including NBS-LRR, Cf2/Cf5 resistance protein, MYB, bZIP, ARF, SCARECROW and WRKY transcription factors. Expression of these identified genes was significantly $(P<0.01)$ upregulated in RRKN-infected plants compared to mock-inoculated plants at 7 days after inoculation.

Conclusion: The identified SNPs enrich the repository of candidate genes for future marker-assisted breeding program to alleviate the damage of RRKN in rice.

\section{Background}

Cereals occupy the major share in global food supply in terms of production, acreage and source of nutrition. Rice as a staple food crop meets the nutrient demand of at least two-thirds of the global population ([1]; http://www.ricepedia.org/). However, the yield of rice is substantially afflicted by several biotrophic pathogens including rice root-knot nematode (RRKN), Meloidogyne graminicola. This sedentary endoparasite occurs in a wide range of rice-based production systems in South and Southeast Asia, including lowland, upland, rainfed, irrigated, deep-water as well as aerobic rice, and causes economic yield loss of rice [2-7]. In the vascular bundle, near the root tip, RRKN induces a feeding site (3-5 giant cells) that serves as the permanent nutrient sink for the nematode. Typical hook-shaped galls are formed around the giant cells that affect water and nutrient translocation of plant and in turn plant growth and several yield-contributing traits (such as root and shoot weight/length, tiller number, panicle/spikelet length, grain weight and percentage filled grains) are impaired $[3-6,8]$.

In order to mitigate the loss by RRKN in rice, use of chemical nematicides, crop rotation (with mung bean, mustard and sesame as poor hosts) and continuous flooding are the recommended practices $[3,6]$. Although prolonged flooding may reduce the RRKN populations by inhibiting the second-stage juveniles (J2) to invade rice roots, increasing scarcity of water for agricultural use may render this practice impractical to adopt. Rotation with other crops during the growing season may incur additional costs to bear for the small-scale rice farmers who constitute a major part of the farming community in Asia. Considering the continual withdrawal of nematicides from the market due to its residual effect on the environment, growing resistant/tolerant rice cultivars offer an economically and environmentally viable option to manage RRKN problems in rice.

Resistance to RRKN has been unraveled in Oryza longistaminata, O. glaberrima (African rice) and even in 0. sativa (Asian rice). Nevertheless, very few of these are truly resistant and majority of Asian rice genotypes are susceptible to $\mathrm{M}$. graminicola [8, 9]. Efforts were made to introgress RRKN resistance from 0 . glaberrima to 0 . sativa, however, interspecific progenies did not exhibit the same degree of resistance documented with 0 . glaberrima $[10,11]$. Resistance to RRKN in rice is reportedly quantitative in nature and governed by several genes with additive effect. Five QTLs (quantitative trait loci, in chromosomes 1, 2, 6, 7 and 9) were found to be associated with root galling by RRKN in RILs (recombinant inbred lines) derived from the cross of O. sativa accessions 'Bala' and 'Azusena' [12]. Jena et al. [13] reported QTLs associated with number of galls and eggs per root system on chromosomes 1 and 3 in RILs derived from the cross of O. sativa accessions 'Annapurna' and 'Ramakrishna'. Likewise, QTLs for resistance and tolerance to RRKN and other yield-contributing traits (such as root and shoot weight, plant height, \% filled grains) were mapped on different chromosomal regions in RILs derived from different O. sativa accessions including 'IR64', 'IR78877-208-B-1-2' and O. glaberrima accession 'CG14' [7, 8].

Genome-wide association study (GWAS) offers a viable strategy to complement traditional bi-parental linkage mapping in order to discern the genetic basis of trait variation [14]. Compared to classical bi-parental QTL mapping, GWAS takes less time to dissect quantitative traits at higher resolution because of the greater recombination rate and distribution of SNP (single nucleotide polymorphism) markers across the genome of natural plant populations. Additionally, prior knowledge of genotype pedigree/crosses is not required in GWAS as bi-allelic 
SNP markers can be used to estimate the population structure [15-17]. To date, only in a few studies, GWAS has been used to identify novel QTLs for phytonematode resistance or susceptibility in different plants including Arabidopsis [18, 19], wheat [20], soybean [21] and rice [22]. QTLs associated with root galling were mapped to the chromosomes 1, 3, 4, 5, 11 and 12 in a global panel of Asian rice [22]. Nevertheless, additional studies on geographically different rice panels (such as wild rice accessions that harbor greater genetic diversity) will enrich the resistant gene pool which can be deployed in future rice breeding programs. Due to ever increasing population pressure and rapid urbanization wild rice resources are depleting at an alarming rate. The Indo-Burma region is considered the biodiversity hotspot of wild rice populations $[23,24]$.

In the present study, we investigated the genetic basis of RRKN resistance in wild rice accessions (constituting 0 . nivara (annual plant), 0. rufipogon (perennial plant) and the intermediate 0 . sativa f. spontanea types) from India using GWAS with a three-pronged approach - (1) screening nematode resistant accessions among 272 diverse rice germplasm, (2) identifying genomic regions significantly associated with RRKN resistance via SNP markers genotyped by 50K "OsSNPnks" genic Affymetrix chip, and (3) expression analysis of candidate genes in nematode-infected plant tissues by quantitative reverse-transcription PCR (qRT-PCR).

\section{Results}

\section{Host response of 272 rice accessions to RRKN infection in Pluronic gel medium}

Screening of 272 rice accessions in Petri dishes (containing Pluronic gel/PF-127 medium) revealed variability in response to RRKN infection at 16 days post inoculation (dpi). Figures $1 \mathrm{a}$ and $1 \mathrm{~b}$ show the frequency distribution of the gall numbers and nematode multiplication factor (MF), respectively, while all values (including numbers of total endoparasites, egg masses and eggs per egg mass) are detailed in Supplementary Table S1. According to Fig. 1a, 49 of the accessions showed highly resistant response (0-2 mean number of galls), 8 exhibited highly susceptible response (7-12 galls), while 87 accessions showed moderately resistant response (4-5 galls). The mean number of galls was recorded to be 7-8 in reference genotypes Taipei 309 and Pusa 1121. A similar trend was observed in terms of MF; a moderate MF value of 12-20 was calculated in maximum of 89 accessions (Fig. 1b). The results of a repeat run with 50 randomly selected accessions revealed a strong correlation with the initial gall $(r=0.780, P<0.001)$ and $M F(r=0.720, P<0.001)$ data, indicating the high reproducibility of PF-127-based assay.

When all the genotypes were categorized into different taxonomic groups of wild rice, accessions from 0 . nivara (2.9 mean numbers of galls) showed the least number of galls as compared to the accessions that are classified as 0 . rufipogon (4.1) and 0. spontanea (5.2). A significant difference $(P<0.01, n>30)$ in gall numbers between different species (Fig. 1C) was found, which explains the genetic variation between wild rice species in our study. When MF values were taken into account a significant difference $(P<0.01, n>30)$ was observed between 0 . spontanea and O. nivara/O. rufipogon but not between O. nivara and O. rufipogon (Fig. 1d). When accessions were stratified into different agro-climatic zones (independent of species), no significant difference was observed. This may be because each geographic location contained all the three species of wild rice (Supplementary Table S2). Although accessions from Mid-Gangetic Plains (MGP; majority of them were $\mathrm{O}$. nivara) showed the least number of galls compared to accessions from other geographic locations (data not shown).

NKSWR 30, an O. nivara accession from MGP, showed no gall in any of the twelve replicates (Fig. 2a, 2b; Supplementary Table S1) whereas NKSWR 11, NKSWR 13, NKSWR 15, NKSWR 18, NKSWR 19, NKSWR 23, NKSWR 25, NKSWR 43, NKSWR 48, NKSWR 108, NKSWR 123, NKSWR 124, NKSWR 128, NKSWR 141, NKSWR 144, NKSWR 156, NKSWR 160 (O. nivara, MGP), NKSWR 259 (O. nivara, Gujarat Plains and Hills (GPH)), NKSWR 101 (O. spontanea, MGP) and IC 336687 (O. rufipogon, East Plateau Hills (EPH)) had only one gall in some of the replicates and zero galls in the remaining replicates (Supplementary Table S1).

\section{Host response of $\mathbf{4 0}$ rice accessions to RRKN infection in soil}

Based on extremely low counts (<2) of gall numbers and MF in PF-127 assay, 40 wild rice accessions were further screened for M. graminicola resistance in soil. Absolute numbers of galls, endoparasites, egg masses, eggs per egg mass and the resultant MF ratio at 16 dpi are detailed in Supplementary Table S3. As an example, the results for some accessions that show low (NKSWR 30, NKSWR 259, NKSWR 43, NKSWR 123, NKSWR 19), medium (NKSWR 101, NKSWR 156, NKSWR 128, NKSWR 15, NKSWR 23) and high (NKSWR 113, NKSWR 13, NKSWR 35, NKSWR 5, NKSWR 39) gall numbers and MF are presented in Figs. 3a and 3b. However, compared to the reference genotype Pusa 1121 (gall number - 41.5 \pm 3.44 ; MF - 61.14 \pm 5.95 ) RRKN infection in the highest susceptible wild rice genotype NKSWR 39 (gall number $-12.5 \pm 1.75$; MF $-8.33 \pm 2.25$ ) was remarkably lower $(P<0.01$; Fig. 3a, 3b). In accordance with the PF-127 assay, 
genotypes NKSWR 30 (gall number $-0.25 \pm 0.05$; MF $-0.02 \pm 0.01$ ) and NKSWR 259 (gall number $-0.25 \pm 0.1$; MF $-0.05 \pm 0.03$ ) showed highly resistant response indicating no $\mathrm{J} 2 \mathrm{~s}$ had penetrated the roots in the majority of the replicates. Moreover, with reference to Taipei 309 and Pusa 1121, comparatively lower number of egg masses, eggs per egg mass and the resultant MF ratio in all the 40 genotypes (Supplementary Table S3) indicate the retarded nematode development and reproduction in selected wild rice accessions. A similar trend was observed when a highly stringent assay was conducted with 40 accessions in PF-127 medium (data not shown).

The number of galls and MF ratio documented in all the 40 accessions in soil assay had correlated very strongly with the identical accessions in PF-127 assay on same parameters ( $r=0.906$ (gall number), $r=0.772$ (MF), $P<0.001$; Fig. 3c, 3d).

\section{Population structure and genetic diversity analysis of wild rice accessions}

For determining the population structure of 270 wild rice accessions and one each of japonica (Taipei 309) and indica (Pusa 1121) cultivars, genotyping was performed using genome-wide unlinked 50K SNPs with no missing data. The Bayesian model-based analysis of population structure of 272 accessions showed the optimum population structure at $\mathrm{K}=3$ (Fig. 4a), suggesting these accessions were stratified into three major genetic sub-populations. Population I (indicated in red color) consisted $38.60 \%$ of accessions (105) in which 84 accessions were pure and 21 were admixed. Population II (indicated in green color) accounted for $22.04 \%$ of accessions (60) of which 17 were admixed. Population III (indicated in blue color) accounted for 39.33\% of accessions (107) of which 19 were admixed (Fig. 4b; Supplementary Figure S1). The mean Fst values for population I, II, and III were $0.4691,0.6877$ and 0.8366 , respectively, exemplifying a considerable proportion of admixture types in our wild rice accessions possibly because of natural intercrossing among these subpopulations. Based on our earlier studies with subsets of these wild rice accessions and their co-clustering with known Aus and Indica rice cultivars ([23]; 418 wild rice accessions were genotyped via 48-plex Illumina GoldenGate assay), the populations I and III are designated as 'Pro-Aus' and 'Pro-Indica' populations, respectively. Pro-Aus and Pro-Indica populations were distributed throughout India, whereas population II was primarily concentrated in MGP and thus designated as 'Mid-Gangetic' population (Fig. 4b; Supplementary Table S2). Notably, Pro-Indica populations contained the highest percentage (28.33\%) of admixture types compared to Pro-Aus (20\%) and MidGangetic (17.75\%) populations.

Diversity analysis revealed 272 rice accessions were grouped into five major clusters (Fig. 4c). Cluster I was split into two sub-clusters, in which majority of Mid-Gangetic populations were nested into sub-cluster la and sub-cluster lb was of mixed type. Majority of Pro-Aus populations were grouped into cluster II which was further subdivided into three sub-clusters each containing a mixture of Pro-Indica and Mid-Gangetic populations. Cluster III and IV was of admixed type containing accessions from diverse agro-climatic zones such as MGP, Upper Gangetic Plains (UGP), Lower Gangetic Plains (LGP), GPH, West Himalayan Regions (WHR), East Himalayan Regions (HER), East Coastal Plains (ECP) and Island Regency (IR). Cluster V nested O. nivara accessions from MGP (Fig. 4c). Our results suggested that population structure analysis may not always conform with diversity analysis as in former case inherent genetic structure are inferred based on their ancestral lineage while in latter genotypes can be grouped into additional clusters according to their geographical origin.

\section{Genome-wide association analysis (GWAS)}

A total of 17 significant SNPs associated with M. graminicola resistance (based on four different parameters including gall number, egg mass, eggs per egg mass and MF) to rice were identified by GWAS using mixed linear model (MLM), which controlled for population structure and familial relatedness (Fig. 5a, 5b; Table 1). The 17 association SNPs explained $5.33-12.61 \%$ of the total phenotypic variation (Table 1). We identified two SNPs to be associated with gall number, appearing to represent two QTLs on chromosome 2 and 6 in rice (threshold for significance $-\log _{10}(P)>4$; Fig. 5; Table 1). Two SNPs each were associated with egg mass (on chromosome 2 and 4 ) and eggs per egg mass (in chromosome 1 and 11). No significant SNPs for total endoparasites were observed (only one SNP was detected at $-\log _{10}(P)>2.75$ ). The greatest number of SNPs (9) was detected (in chromosome 1, 2, 3, 4, 6, 10 and 11) to be associated with the most important trait, i.e. nematode multiplication factor $\left(-\log _{10}(P)>4\right.$; Fig. 5; Table 1). Overall, two QTLs on chromosome 1 and 4 were found to be associated with all the traits (Table 1). Percent heritability explained by corresponding SNPs for phenotypic traits such as gall number, egg mass, eggs per egg mass and MF were 78, 71, 65 and 89\%, respectively (Table 2). 
Table 1

Significant SNP markers associated with QTLs conferring resistance to M. graminicola in 272 rice accessions. Note that QTL 1.3 and 4.4 are common for all the traits. $\mathrm{R}^{2}$ - phenotypic variation explained by the corresponding SNP. Rice locus IDs are provided as gene models.

TF - transcription factor.

\begin{tabular}{|c|c|c|c|c|c|c|c|c|c|}
\hline $\begin{array}{l}\text { Suspected } \\
\text { QTLs }\end{array}$ & Trait & SNP ID & Chromosome & $\begin{array}{l}\text { Position } \\
\text { (bp) }\end{array}$ & $\begin{array}{l}P \text { - } \\
\text { value }\end{array}$ & $\begin{array}{l}\mathrm{R}^{2} \\
(\%)\end{array}$ & MAF & $\begin{array}{l}\text { SNP located in } \\
\text { gene }\end{array}$ & $\begin{array}{l}\text { Genes in } \\
200 \text { kb LD }\end{array}$ \\
\hline 1.1 & $\begin{array}{l}\text { Eggs/egg } \\
\text { mass }\end{array}$ & $\begin{array}{l}\text { AX- } \\
95940548\end{array}$ & 1 & $6,008,298$ & $\begin{array}{l}5.82 \mathrm{E}- \\
04\end{array}$ & 12.61 & 0.49 & $\begin{array}{l}\text { LOC_Os01g11230 } \\
\text { (heme-binding } \\
\text { protein) }\end{array}$ & $\begin{array}{l}\text { Os01g11110, } \\
\text { 11350 (bZIP } \\
\text { TF), } \\
\text { Os01g11200 } \\
\text { (MYB TF), } \\
\text { Os01g11150 } \\
\text { (gibberellin) }\end{array}$ \\
\hline 1.2 & MF & $\begin{array}{l}\text { AX- } \\
95961959\end{array}$ & 1 & $10,396,769$ & $\begin{array}{l}4.30 \mathrm{E}- \\
04\end{array}$ & 7.72 & 0.52 & $\begin{array}{l}\text { Os01g18490 } \\
\text { (expressed } \\
\text { protein) }\end{array}$ & $\begin{array}{l}\text { Os01g18440 } \\
\text { (MADS-box } \\
\text { protein), } \\
\text { Os01g18584 } \\
\text { (WRKY9) }\end{array}$ \\
\hline 1.3 & $\begin{array}{l}\text { Galls, } \\
\text { Egg } \\
\text { mass, } \\
\text { Eggs/egg } \\
\text { mass, } \\
\text { MF }\end{array}$ & $\begin{array}{l}\text { AX- } \\
95964807\end{array}$ & 1 & $34,895,044$ & $\begin{array}{l}3.24 \mathrm{E}- \\
04\end{array}$ & 7.49 & 0.44 & $\begin{array}{l}\text { Os01g60330 } \\
\text { (ubiquitin- } \\
\text { conjugating } \\
\text { receptor kinase) }\end{array}$ & $\begin{array}{l}\text { Os01g60060 } \\
\text { (leucine-rich } \\
\text { repeat), } \\
\text { Os01g60440 } \\
\text { (HEAT } \\
\text { repeat), } \\
\text { Os01g60490 } \\
\text { (WRKY22), } \\
\text { Os01g60520 } \\
\text { (WRKY116), } \\
\text { Os01g60540 } \\
\text { (WRKY20), } \\
\text { Os01g60600 } \\
\text { (WRKY108) }\end{array}$ \\
\hline 2.1 & MF & $\begin{array}{l}\text { AX- } \\
95945545\end{array}$ & 2 & $13,183,197$ & $\begin{array}{l}9.42 E- \\
04\end{array}$ & 6.69 & 0.39 & $\begin{array}{l}\text { Os02g22140 } \\
\text { (GTP binding } \\
\text { ADP-ribosylation } \\
\text { factor) }\end{array}$ & $\begin{array}{l}\text { Os02g22020 } \\
\text { (MYB TF) }\end{array}$ \\
\hline 2.2 & Galls & $\begin{array}{l}\text { AX- } \\
95921578\end{array}$ & 2 & $24,480,888$ & $\begin{array}{l}2.47 \mathrm{E}- \\
04\end{array}$ & 9.24 & 0.32 & $\begin{array}{l}\text { Os02g40420 } \\
\text { (expressed } \\
\text { protein) }\end{array}$ & $\begin{array}{l}\text { Os02g40430 } \\
\text { (HEAT } \\
\text { repeat), } \\
\text { Os02g40450 } \\
\text { (DEAD/DEAH } \\
\text { box), } \\
\text { Os02g40530 } \\
\text { (MYB TF), } \\
\text { Os02g40664 } \\
\text { (zinc finger) }\end{array}$ \\
\hline 2.3 & $\begin{array}{l}\text { Egg } \\
\text { mass }\end{array}$ & $\begin{array}{l}\text { AX- } \\
95947392\end{array}$ & 2 & $24,526,132$ & $\begin{array}{l}8.59 E- \\
04\end{array}$ & 8.32 & 0.33 & $\begin{array}{l}\text { Os02g40450 } \\
\text { (DEAD/DEAH } \\
\text { box) }\end{array}$ & $\begin{array}{l}\text { Same as } \\
\text { above }\end{array}$ \\
\hline 3.1 & MF & $\begin{array}{l}\text { AX- } \\
95935442\end{array}$ & 3 & $27,655,564$ & $\begin{array}{l}8.69 \mathrm{E}- \\
04\end{array}$ & 10.35 & 0.30 & $\begin{array}{l}\text { Os03g48490 } \\
\text { (centromere } \\
\text { protein) }\end{array}$ & $\begin{array}{l}\text { Os03g48450 } \\
\text { (SCARECROW } \\
\text { TF), } \\
\text { Os03g48600 } \\
\text { (auxin- } \\
\text { regulated } \\
\text { protein, } \\
\text { DUF966) }\end{array}$ \\
\hline
\end{tabular}




\begin{tabular}{|c|c|c|c|c|c|c|c|c|c|}
\hline $\begin{array}{l}\text { Suspected } \\
\text { QTLs }\end{array}$ & Trait & SNP ID & Chromosome & $\begin{array}{l}\text { Position } \\
\text { (bp) }\end{array}$ & $\begin{array}{l}\mathrm{P} \text { - } \\
\text { value }\end{array}$ & $\begin{array}{l}R^{2} \\
(\%)\end{array}$ & MAF & $\begin{array}{l}\text { SNP located in } \\
\text { gene }\end{array}$ & $\begin{array}{l}\text { Genes in } \\
200 \mathrm{~kb} \text { LD }\end{array}$ \\
\hline 4.1 & $\begin{array}{l}\text { Egg } \\
\text { mass }\end{array}$ & $\begin{array}{l}\text { AX- } \\
95925342\end{array}$ & 4 & $27,068,142$ & $\begin{array}{l}1.22 \mathrm{E}- \\
05\end{array}$ & 10.89 & 0.40 & $\begin{array}{l}\text { Os04g45740 } \\
\text { (hypothetical } \\
\text { protein) }\end{array}$ & $\begin{array}{l}\text { Os04g45460 } \\
\text { (cysteine-rich } \\
\text { secretory } \\
\text { protein), } \\
\text { Os04g45690 } \\
\text { (B-box zinc } \\
\text { finger), } \\
\text { Os04g45810 } \\
\text { (leucine } \\
\text { zipper), } \\
\text { Os04g45960 } \\
\text { (subtilisin } \\
\text { protease), } \\
\text { Os04g46020 } \\
\text { (GATA zinc } \\
\text { finger), } \\
\text { Os04g46060 } \\
\text { (WRKY36) }\end{array}$ \\
\hline 4.2 & MF & $\begin{array}{l}\text { AX- } \\
95964658\end{array}$ & 4 & $29,863,576$ & $\begin{array}{l}4.84 \mathrm{E}- \\
05\end{array}$ & 7.92 & 0.28 & $\begin{array}{l}\text { Os04g50070 } \\
\text { (C2H2 zinc finger) }\end{array}$ & $\begin{array}{l}\text { Os04g49890, } \\
\text { Os04g49900 } \\
\text { (ABC } \\
\text { transporter), } \\
\text { Os04g49950 } \\
\text { (F-box } \\
\text { protein), } \\
\text { Os04g49980 } \\
\text { (LEA protein), } \\
\text { Os04g50060 } \\
\text { (GRAS TF), } \\
\text { Os04g50100 } \\
\text { (RING H2 zinc } \\
\text { finger), } \\
\text { Os04g50200 } \\
\text { (F-box } \\
\text { protein), } \\
\text { Os04g50660 } \\
\text { (WD protein), } \\
\text { Os04g50680, } \\
50770 \text { (MYB } \\
\text { TF), } \\
\text { Os04g50700, } \\
50710 \text { (PR } \\
\text { protein), } \\
\text { Os04g50720, } \\
50740,50760 \\
\text { (RING zinc } \\
\text { finger) }\end{array}$ \\
\hline 4.3 & MF & $\begin{array}{l}\text { AX- } \\
95924928\end{array}$ & 4 & $29,916,160$ & $\begin{array}{l}9.55 \mathrm{E}- \\
04\end{array}$ & 6.43 & 0.39 & $\begin{array}{l}\text { Os04g50160 } \\
\text { (retrotransposon } \\
\text { protein) }\end{array}$ & $\begin{array}{l}\text { Os04g50660 } \\
\text { (WD protein), } \\
\text { Os04g50680, } \\
50770 \text { (MYB } \\
\text { TF), } \\
\text { Os04g50700, } \\
50710 \text { (PR } \\
\text { protein), } \\
\text { Os04g50720, } \\
50740,50760 \\
\text { (RING zinc } \\
\text { finger), } \\
\text { Os04g50920 } \\
\text { (WRKY37) }\end{array}$ \\
\hline 4.4 & $\begin{array}{l}\text { Galls, } \\
\text { Egg } \\
\text { mass, } \\
\text { Eggs/egg } \\
\text { mass, } \\
\text { MF }\end{array}$ & $\begin{array}{l}\text { AX- } \\
95939714\end{array}$ & 4 & $30,155,892$ & $\begin{array}{l}4.56 \mathrm{E}- \\
04\end{array}$ & 9.89 & 0.42 & NA & $\begin{array}{l}\text { Same as } \\
\text { above, } \\
\text { Os04g51172 } \\
\text { (zinc finger) }\end{array}$ \\
\hline
\end{tabular}




\begin{tabular}{|c|c|c|c|c|c|c|c|c|c|}
\hline $\begin{array}{l}\text { Suspected } \\
\text { QTLs }\end{array}$ & Trait & SNP ID & Chromosome & $\begin{array}{l}\text { Position } \\
\text { (bp) }\end{array}$ & $\begin{array}{l}\mathrm{P} \text { - } \\
\text { value }\end{array}$ & $\begin{array}{l}R^{2} \\
(\%)\end{array}$ & MAF & $\begin{array}{l}\text { SNP located in } \\
\text { gene }\end{array}$ & $\begin{array}{l}\text { Genes in } \\
200 \mathrm{~kb} \text { LD }\end{array}$ \\
\hline 6.1 & MF & $\begin{array}{l}\text { AX- } \\
95936929\end{array}$ & 6 & $28,018,736$ & $\begin{array}{l}4.21 \mathrm{E}- \\
05\end{array}$ & 7.32 & 0.35 & $\begin{array}{l}\text { Os06g46250 } \\
\text { (expressed } \\
\text { protein) }\end{array}$ & $\begin{array}{l}\text { Os06g45970 } \\
\text { (auxin- } \\
\text { responsive } \\
\text { gene), } \\
\text { Os06g46240 } \\
\text { (BTB/POZ } \\
\text { domain), } \\
\text { Os06g46366 } \\
\text { (C3HC4 zinc } \\
\text { finger), } \\
\text { Os06g46410 } \\
\text { (auxin } \\
\text { response } \\
\text { factor), }\end{array}$ \\
\hline 6.2 & Galls & $\begin{array}{l}\text { AX- } \\
95927509\end{array}$ & 6 & $28,651,370$ & $\begin{array}{l}9.18 \mathrm{E}- \\
06\end{array}$ & 9.91 & 0.38 & $\begin{array}{l}\text { Os06g } 47260 \\
\text { (GTP binding Rac } \\
\text { protein) }\end{array}$ & $\begin{array}{l}\text { Os06g47150 } \\
\text { (auxin } \\
\text { response } \\
\text { factor), } \\
\text { Os06g47200 } \\
\text { (protease } \\
\text { inhibitor), } \\
\text { Os06g47230 } \\
\text { (coiled-coil } \\
\text { domain), } \\
\text { Os06g47270 } \\
\text { (C3HC4 zinc } \\
\text { finger) }\end{array}$ \\
\hline 10.1 & MF & $\begin{array}{l}\text { AX- } \\
95938411\end{array}$ & 10 & $17,990,076$ & $\begin{array}{l}8.05 \mathrm{E}- \\
05\end{array}$ & 8.53 & 0.28 & NA & $\begin{array}{l}\text { Os10g33810 } \\
\text { (MYB TF), } \\
\text { Os10g33940 } \\
\text { (auxin } \\
\text { response } \\
\text { factor), } \\
\text { Os10g34000 } \\
\text { (aquaporin), } \\
\text { Os10g34030 } \\
\text { (C3HC4 zinc } \\
\text { finger), } \\
\text { Os34040 } \\
\text { (nodulin) }\end{array}$ \\
\hline 11.1 & MF & $\begin{array}{l}\text { AX- } \\
95961774\end{array}$ & 11 & $2,694,492$ & $\begin{array}{l}2.16 \mathrm{E}- \\
05\end{array}$ & 5.33 & 0.36 & NA & $\begin{array}{l}\text { Os11g05640 } \\
\text { (bZIPTF), } \\
\text { Os11g05660 } \\
\text { (F-box } \\
\text { protein), } \\
\text { Os11g05800 } \\
\text { (abscisic acid } \\
\text { induced } \\
\text { HVA22) }\end{array}$ \\
\hline 11.2 & MF & $\begin{array}{l}\text { AX- } \\
95933197\end{array}$ & 11 & $5,848,427$ & $\begin{array}{l}8.98 \mathrm{E}- \\
04\end{array}$ & 7.13 & 0.37 & NA & $\begin{array}{l}\text { Os11g10550, } \\
10570, \\
10610, \\
10620,10760 \\
\text { (NBS-LRR } \\
\text { protein), } \\
\text { Os11g10720 } \\
\text { (cf2/cf5 } \\
\text { resistance } \\
\text { gene), } \\
\text { Os11g10770 } \\
\text { (RGA3 } \\
\text { resistance } \\
\text { protein) }\end{array}$ \\
\hline
\end{tabular}




\begin{tabular}{|c|c|c|c|c|c|c|c|c|c|}
\hline $\begin{array}{l}\text { Suspected } \\
\text { QTLs }\end{array}$ & Trait & SNP ID & Chromosome & $\begin{array}{l}\text { Position } \\
\text { (bp) }\end{array}$ & $\begin{array}{l}\mathrm{P} \text { - } \\
\text { value }\end{array}$ & $\begin{array}{l}\mathrm{R}^{2} \\
(\%)\end{array}$ & MAF & $\begin{array}{l}\text { SNP located in } \\
\text { gene }\end{array}$ & $\begin{array}{l}\text { Genes in } \\
200 \mathrm{~kb} \text { LD }\end{array}$ \\
\hline 11.3 & $\begin{array}{l}\text { Eggs/egg } \\
\text { mass }\end{array}$ & $\begin{array}{l}\text { AX- } \\
95960766\end{array}$ & 11 & $20,145,250$ & $\begin{array}{l}4.00 \mathrm{E}- \\
04\end{array}$ & 10.75 & 0.35 & $\begin{array}{l}\text { Os11g34370 } \\
\text { (phospholipase) }\end{array}$ & $\begin{array}{l}\text { Os11g34450 } \\
\text { (14-3-3 } \\
\text { protein), } \\
\text { Os11g34460 } \\
\text { (F-box } \\
\text { protein), } \\
\text { Os11g34660 } \\
\text { (protease } \\
\text { inhibitor), } \\
\text { Os11g34700 } \\
\text { (C2H2 zinc } \\
\text { finger) }\end{array}$ \\
\hline
\end{tabular}

Table 2

Percent heritability of different phenotypic traits with corresponding number of significantly associated SNPs. $\mathrm{R}^{2}$ reflects the amount of heritable variation explained by an additive model of the SNPs (ANOVA).

\begin{tabular}{|lllllll|}
\hline Trait & $-\log _{10}(P)$ & Significant SNPs & $\mathbf{R}^{2}$ & F value & P value & $\%$ heritability \\
\hline Galls & $>4$ & 4 & 0.403169 & 12.98 & 0.0009 & $78 \%$ \\
\hline Egg mass & $>4$ & 4 & 0.363193 & 10.47 & 0.001 & $71 \%$ \\
\hline Eggs/Egg mass & $>3$ & 4 & 0.282387 & 9.78 & 0.002 & $65 \%$ \\
\hline MF & $>4$ & 11 & 0.49924 & 15.98 & 0.0002 & $89 \%$ \\
\hline
\end{tabular}

In accordance with Dimkpa et al. (2016), herein, QTLs were considered to be within $200 \mathrm{~kb}$ of a significant SNP. This $200 \mathrm{~kb}$ window falls within the estimated window of LD decay $(\sim 50-500 \mathrm{~kb})$ in rice [25-28]. More specifically, in wild rice LD decays at approximately $1-$ $200 \mathrm{~kb}$ (0. nivara maintains LD over larger distance due to their high level of self-pollination; [29]). Notably, O. nivara constituted $66.67 \%$ of total wild rice accessions in our study (Supplementary Table S2). Based on the detailed annotations in Rice Genome Annotation Project and NCBI, we identified candidate genes either flanking or within the $200 \mathrm{~kb}$ region on each side of the 17 associated SNPs (Table 1). A number of transcription factors (TFs) including leucine zipper (bZIP), SCARECROW, MYB, MADS-box, WRKY, auxin response factor (ARF), GRAS etc. (regulate plant defense gene expression during pathogen stress) were located on different chromosomes (Table 1). Several resistance proteins such as leucine-rich repeat (LRR), NBS-LRR, Cf2/Cf5, RGA3, Lr34 analog ABC transporter, zinc finger motifs, WD repeat, F-box (analogous to WD and LRR) were located in different QTLs (Table 1). Additionally, a number of protein kinases, Exo70 exocyst complex and kelch motifs were identified which are not listed in Table 1. Gibberellin, pathogenesis-related (PR) proteins, HEAT repeats and 14-3-3 proteins which are required for plant immunity to pathogen stress were also identified. Aquaporin, nodulin and auxin regulatory proteins were identified which are known to regulate the giant cell initiation and maintenance during nematode infection (Table 1).

Interestingly, a number of NBS-LRR proteins were located in QTL 11.2. Similarly, QTLs 1.3 and 4.2 were rich in WRKY TFs and zinc fingers, respectively. However, many candidate genes were common between QTL 2.2 and $2.3\left(r^{2}=0.75\right), 4.2$ and $4.3\left(r^{2}=0.7\right), 4.3$ and $4.4\left(r^{2}=\right.$ 0.55), as they were within 200-kb LD (Table 1). SNPs were located within the candidate genes in QTL 1.3 (ubiquitin-conjugating receptor kinase), 2.1 (ADP-ribosylation factor), 2.3 (DEAD/DEAH-box helicase), 4.2 (zinc finger) and 6.2 (GTP-binding Rac protein).

\section{qRT-PCR-based expression analysis of candidate genes}

To further test the role of selective candidate genes in resistance of rice to M. graminicola infection, qRT-PCR was performed in infected and uninfected root tissues of Pusa 1121 seedlings. Expression of the fourteen genes was quantified in whole roots collected at the time of nematode inoculation and at $7 \mathrm{dpi}$ in infected and uninfected plants. This enabled us to investigate the developmental regulation of the genes in young rice seedlings, as well as their regulation upon nematode infection. Except LOC_Os01g18440 (MADS-box), Os02g22140 (ADP-ribosylating protein), Os03g48450 (SCARECROW TF), Os04g50070 (zinc finger) and Os11g34450 (F-box), all the candidate genes were significantly $(P<0.05)$ upregulated in mock-inoculated plants $(7 \mathrm{dpi})$ compared to 0 dpi control plants (Fig. 6). The temporal expression of Os01g11200 (MYB TF), ADP-ribosylating protein, SCRECROW TF, zinc finger, Os06g47260 (Rac protein), Os11g05640 (bZIP TF), Os11g10720 (Cf2/Cf5), Os11g10760 (NBS-LRR) and Os11g34450 (14-3-3) was significantly $(P<0.05)$ elevated in RRKN-infected roots at 7 days after inoculation (Fig. 6), suggesting these genes may have a role in eliciting the defense response against M. graminicola. In contrast, expression of MADS-box, Os02g40450 (DEAD-box), Os04g50660 (WD repeat) and F-box protein was unaltered $(P>0.05)$ in 7

Page $8 / 22$ 
dpi infected plants compared to $7 \mathrm{dpi}$ uninfected plants. Intriguingly, steady-state mRNA levels of Os10g33940 (ARF18) was significantly $(\mathrm{P}<0.05)$ attenuated in $7 \mathrm{dpi}$ infected plants than $7 \mathrm{dpi}$ uninfected ones (Fig. 6), indicating the role of this gene in rice to RRKN susceptibility.

\section{Discussion}

\section{Broad and novel genetic resources for M. graminicola resistance in rice}

The wild relatives of rice harbor rich and novel genetic resources which can be used to improve pest and disease resistance in cultivated rice $[30,31]$. For example, resistance to grassy stunt virus, bacterial leaf blight, neck blast and brown plant hopper was successfully introgressed into the cultivated rice from their wild relatives [32-34]. A number of beneficial traits including tolerance to biotic and abiotic stresses have been lost in cultivated rice which possesses a narrow genetic base because of domestication and breeding bottlenecks [23, 24]. According to an estimate, modern rice varieties have retained only $20 \%$ of the genetic diversity present in their wild relatives [35]. India has unprecedented diversity of wild rice germplasm and landraces that are spread over fifteen diverse agro-climatic zones [23, 24]. Therefore, these untapped genetic resources were taken as the prime candidates for the association panel in our study in order to unravel the conserved loci that govern M. graminicola resistance in rice. Indeed, a large proportion (14.8\%; 40 of 270 accessions) of the wild accessions was found to be highly resistant to M. graminicola infection in the present study.

Herein, we screened 272 diverse rice accessions collected from ten agro-climatic zones for $\mathrm{M}$. graminicola resistance by measuring the relative numbers of galls, endoparasites, egg mass, eggs per egg mass and MF ratio in PF-127 medium. A significant variation in the susceptibility level of rice accessions to RRKN infection was documented. A repeat experiment with fifty randomly selected accessions from this diversity panel showed strong correlation with the initial screening results. This suggests that PF-127-based screening is a robust and reproducible method for dissecting the rice-RRKN interaction, in agreement with the previous reports from our laboratory [36, 37]. In addition, 40 highly resistant accessions were further evaluated for $\mathrm{M}$. graminicola resistance in large plug trays containing soil as the medium. Taken together the data of both soil- and PF-127-based screening, O. nivara accessions NKSWR 30 and NKSWR 259 showed almost immune response to $\mathrm{M}$. graminicola with zero galls and zero MF in majority of the replicates at $16 \mathrm{dpi}$. Other $\mathrm{O}$. nivara accessions such as NKSWR 43, NKSWR 123, NKSWR 19, NKSWR 108, NKSWR 25, NKSWR 18 and a O. rufipogon accession IC 336687 also supported extremely low population level of M. graminicola. The negligible susceptibility of these accessions cannot be attributed to poor root growth because root weight of these accessions was comparable with that of susceptible accessions (data not shown). The differential susceptibility of $332 \mathrm{O}$. sativa accessions to M. graminicola was earlier reported via soil-based screening in which two accessions LD 24 (indica) and Khao Pahk Maw (aus) were found to be almost immune to RRKN infection [22, 38].

Among 40 highly resistant wild accessions, 34 belonged to 0 . nivara type (33 of them collected from middle Gangetic plains agro-climatic zone) whereas 3 each belonged to 0 . rufipogon and 0 . sativa f. spontanea types. According to PF-127-based screening, a clear difference in resistance level in 272 accessions was also evident when genotypes were categorized into different taxonomic groups, i.e. nivara-, rufipogon- and spontanea-type. These differences can be explained by the possibility of different selection pressures among the geographic regions. When compared within different agro-climatic zones, accessions from MGP showed least nematode infection. The majority of resistant accessions originally from middle Gangetic plains (occupies the eastern part of Uttar Pradesh and Bihar) presumably have experienced higher selection pressure from RRKN infection. A similar stratification of cyst nematode (Heterodera glycines) resistance level across the different geographic location of soybean crop was reported when 235 wild accessions were included for association mapping analysis [21].

The genetic variation among Indian wild rice accessions were studied via model-based population structure analysis using genome-wide unlinked SNP markers (unlinked markers provide high reproducibility and success rate of population structure analysis; [39]) which grouped the accessions into three distinct subpopulations, namely Pro-Aus, Pro-Indica and Mid-Gangetic populations. Additionally, genetic diversity and cluster analysis based on SNP markers revealed the current wild accessions were highly diverse indicating each populations of an agro-climatic zone constituted mixture of genetically diverse individuals. According to the Fst values, Pro-Indica and Mid-Gangetic populations contained the greatest and least proportion of admixture types, respectively. Thus, accessions collected from middle Gangetic plains agro-climatic zone represented a conserved wild rice subpopulation whereas relatively greater level of gene flow and outcrossing was speculated among the geographically adjacent than the distant populations. Notably, overlapping geographic distribution pattern of wild rice subpopulations was reported by several studies [29, 40,41]. Due to their open inflorescence the sympatric species, 0 . nivara and 0 . rufipogon can outcross with each other and also with cultivated $O$. sativa $[42,43]$. Nevertheless, the greater genetic diversity of present wild rice accessions is in line with the hypothesis that wild rice are the source of useful new genes for future varietal improvement program $[30,44]$. 
Phenotyping of the association panel has offered important information about the degree and distribution of RRKN susceptibility in Indian wild rice species including 0 . nivara, O. rufipogon and O. sativa f. spontanea, and in two cultivated species, i.e. O. sativa indica and japonica. This provided new insights into the evolution of resistance/susceptibility of wild and cultivated rice species to M. graminicola parasitism. The higher susceptibility of indica and especially japonica rice is not surprising maybe because no selection is in function to introduce resistance in japonica as RRKN is not a pest of temperate rice cultivation [22]. Intriguingly, a majority of O. nivara accessions from middle Gangetic plains (a suspected genetic diversity hotspot; [23]) has shown the least susceptibility to RRKN infection. This may be because of their eco-geographical isolation in accordance with the rationale that gene flow is inversely related to geographic distance of natural populations [45].

\section{Genetic loci determining the parasitic success of M. graminicola in rice}

By analyzing the marker-trait associations in 272 rice accessions via GWAS, we identified 17 significant SNPs that governed the RRKN resistance-related traits such as numbers of galls, egg mass, eggs per egg mass and MF ratio. By applying the $-\log _{10}(P)$ score of 4 as a threshold for significance, we identified two QTLs at chromosome 1 and 4 of rice were associated with all the traits. A similar stringency level or a less stringent threshold $\left(-\log _{10}(P)>3\right)$ was adopted while reporting significant SNPs associated with nematode resistance/susceptibility in rice [22], wheat [20], soybean [21] and Arabidopsis [46]. In particular, four SNPs in chromosome 4, three SNPs each in chromosome 1, 2, 11, two SNPs in chromosome 6, and one SNP each in chromosome 3 and 10 were found to be associated with different traits. The trait such as total endoparasite counts in rice accessions was not taken into consideration as only one SNP was detected for this trait at $-\log _{10}(P)>2.75$. Lowering the threshold for significance in GWAS study may increase the false discovery rate which in turn reveals more common alleles with smaller effect size in test populations [19].

A number of transcription factors (bZIP, SCARECROW, MYB, MADS-box, WRKY, ARF, GRAS etc.) that regulate plant defense responses to nematode and various biotic stress [47-54], were located on different chromosomes within 200-kb LD of the suspected QTLs in this study. The $200 \mathrm{~kb}$ window was adopted because of the fact that LD decay occurs in rice at 50-500 kb [25-28]. Although in wild rice the decay is much higher at 1-200 kb, O. nivara maintains LD over larger distance due to their high level of self-pollination [29]. Notably, O. nivara constituted $66.67 \%$ of total wild rice accessions in our study. Other important candidate genes located in different QTLs include resistance genes such as NBS-LRR, Cf2/Cf5, RGA3, Lr34 analog ABC transporter, zinc finger, WD repeat, leucine-rich repeat, HEAT repeat etc. All these genes putatively function to elicit plant innate immunity during pathogen invasion [55-58]. A number of candidate genes putatively involved in plant defense response to biotic stress were located within the SNPs in QTL 1.3 (ubiquitin-conjugating receptor kinase; [59, 60]), 2.1 (ADP-ribosylation factor; [61]), 2.3 (DEAD/DEAH-box; [62]), 4.2 (zinc finger; [57]) and 6.2 (GTP-binding Rac protein; [63, 64]) in our study.

We assume that chromosomes 1 (QTL 1.3 harbored a number of WRKY TF), 2, 4 (QTL 4.2 contained several zinc finger motifs), 6 and 11 (QTL 11.2 displayed several NBS-LRR resistance genes) might play a decisive role in contributing resistance to M. graminicola in rice because a number of significant SNP loci were identified in each of these chromosomes. A previous association mapping analysis have identified chromosomes 4 and 11 to harbor candidate genes such as lectin and homolog of stripe rust resistance protein [22]. Using RILbased bi-parental mapping study, QTLs for RRKN resistance were identified on almost all the 12 chromosomes of rice to date $[7,8,12,13]$. It is evident that RRKN resistance in rice is a complex trait that involves a number of genes which regulate a cascade of plant defense responses. Therefore, unravelling the conserved and novel RRKN-resistance loci from the non-domesticated wild rice population could improve our understanding of molecular mechanisms underlying the rice-RRKN interaction.

\section{Candidate genes involved in M. graminicola resistance in rice}

Unlike a report of homologous stripe rust and powdery mildew resistance genes in chromosome 11 of 0 . sativa [22], no information is available about the canonical nucleotide-binding leucine-rich repeat (NB-LRR)-type genes that impart resistance against M. graminicola in rice. Herein, we report a number of NBS-LRR proteins (LOC_Os11g10550, 10570, 10610, 10620 and 10760) which was mapped on

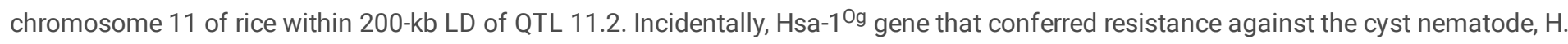
sacchari, was mapped on chromosome 11 of 0 . glaberrima [65]. The nucleotide-binding state of NBS-LRR proteins regulates the activity of plant resistance $(R)$ proteins that are involved in activation of plant innate immunity upon pathogen recognition [66]. The $R$ gene in tomato contains Cf2/Cf5 locus (encode LRR) that confer resistance in tomato to M. incognita [55]. Upon pathogen invasion in host plants, the activated membrane-bound NBS-LRR immune receptors translocate to the cell nucleus and interact with specific transcription factors (although not exclusive, comprise members of ERF, bHLH, bZIP, MYB, NAC and WRKY families) which modulate the plant immunity [50]. In

Page $10 / 22$ 
our qRT-PCR analysis, compared to uninfected plants the expression of NBS-LRR and Cf2/Cf5 protein was positively regulated in M. graminicola-infected Pusa 1121 at $7 \mathrm{dpi}$. In coherence, other defense response regulatory genes such as MYB TF, SCARECROW, zinc fingers, bZIP TF and 14-3-3 were upregulated in nematode-infected plants than the uninfected ones.

Overexpression of a rice ADP-ribosylation factor induced pathogen resistance in tobacco by regulating the transcript accumulation of pathogenesis-related (PR) genes and salicylic acid (SA) [61]. OsRac1 (GTP binding Rac protein) was shown to be a component of disease resistance pathway acting downstream of $\mathrm{R}$ gene when OsRac1 transformed japonica rice was infected with the blast fungus, Magnaporthe oryzae [63]. Increased resistance to tobacco mosaic virus was documented when tobacco was transformed with OsRac1 $[64,67]$. In our qRT-PCR study, both ADP-ribosylating and Rac protein was substantially upregulated in M. graminicola infected plants than the uninfected ones at $7 \mathrm{dpi}$. Together, our data suggest changes in expression level of these candidate genes can be a contributory factor to confer resistance in rice to M. graminicola. However, expression of ARF18 TF (auxin response factor) was downregulated in nematodeinfected plants compared to uninfected plants at $7 \mathrm{dpi}$ in our qRT-PCR study. Auxin-regulated proteins are known to coordinate the balance between plant root growth and disease resistance by promoting the auxin biosynthesis and suppressing the benzoxazinoid-based defense compound formation [68]. The direct role of auxin influx (AUX1, LAX3) and efflux (PIN3) proteins in giant cell formation were unraveled during Arabidopsis-M. incognita compatible interaction [69].

\section{Conclusions}

In conclusion, forty accessions displaying a high degree of resistance to M. graminicola were identified. This data uncovers the potential of O. nivara, O. rufipogon and O. sativa f. spontanea as novel resources for RRKN management. GWAS was successfully applied to dissect the genetic architecture of resistance to RRKN in Indian wild rice populations. The present study provides an example of exploring the untapped genetic resources and novel genes which enrich the repository of candidate genes utilizable for future marker-assisted rice breeding program for RRKN resistance.

\section{Methods}

\section{Plant materials}

A set of 272 diverse genotypes were used in the present study. The set included 270 wild rice accessions (O. nivara/O. rufipogon/O. sativa f. spontanea) collected from different agro-climatic zones of India; 156 from Mid Gangetic Plains (MGP), 14 from Upper Gangetic Plains (UGP), 12 from Lower Gangetic Plains (LGP), 20 from West Himalayan Regions (WHR), 9 from East Himalayan Regions (EHR), 22 from West Coastal Plains (WCP), 3 from East Coastal Plains (ECP), 5 from East Plateau Hills (EPH), 23 from Gujarat Plains and Hills (GPH), and 6 from Island Regency (IR). As reference genotypes, O. sativa elite cultivars 'Pusa 1121' (indica) and 'Taipei 309' (japonica) were used. Details of the rice accessions used in the current study are provided in Supplementary Table S2 and the online database at http://nksingh.nationalprof.in:8080/iwrdb/index.jsp.

\section{Nematode culture}

A pure culture of an Indian isolate of M. graminicola Golden \& Birchfield was maintained on rice (O. sativa cv. Pusa 1121) in a greenhouse. Egg masses were collected from galled roots via sterilized forceps and were kept for hatching on a double-layered tissue paper supported on a mould sieve of wire gauze in a Petri dish containing distilled water. Freshly hatched second stage juveniles (J2s) were used for subsequent experiments.

\section{Rice accessions screening assay}

Seeds of different rice accessions were surface-sterilized via $70 \%$ ethanol prior to soaking overnight in distilled water. Seeds were germinated in Petri dish containing wet filter paper in a growth chamber at $28 \pm 2{ }^{\circ} \mathrm{C}$ and $4-5$ days old seedlings were used for infection bioassays in Pluronic gel medium (PF-127, Sigma-Aldrich) as described previously [36, 37]. Briefly, $60 \mathrm{ml}$ of $23 \%$ PF-127 was poured into $150 \times 20 \mathrm{~mm}$ Petri dish containing 7-9 uniformly distributed seedlings of identical genotype at $<15^{\circ} \mathrm{C}$ and approximately $30 \mathrm{RRKN} \mathrm{J} 2 \mathrm{~s}$ were inoculated at the root tip of each seedling by a pipette tip. The gel was set at room temperature and Petri plates were incubated at $28^{\circ} \mathrm{C}$ and 14: $10 \mathrm{~h}$ light: dark photoperiod in a growth chamber (light level $-300 \mu \mathrm{mol} \mathrm{m}^{-2} \mathrm{~s}^{-1}$ ). At $16 \mathrm{dpi}$, plantlets were extracted from PF-127 by placing the dishes in an ice bath as the gel liquefies below $15^{\circ} \mathrm{C}$. Roots were stained with acid fuchsin [70], galls were dissected under the microscope, and the number and stage of penetrated nematodes were recorded. Photomicrographs were obtained in a Zeiss Axiocam MRm microscope. Nematode multiplication factor (MF) ratio was calculated [(number of egg masses $\times$ number of eggs per egg 
mass) $\div$ nematode inoculum level] to determine the reproductive potential of RRKN in different rice accessions. For each accession three plates were included and the experiment was repeated at least twice.

\section{Host response of 40 rice accessions to RRKN infection in soil and PF-127}

After initial screening of 272 accessions in PF-127 medium, 40 accessions were selected (based on lower counts $(<2)$ of gall and MF value) for further screening based on root galling, total endoparasite counts and MF. Plug trays with 50 wells [ $45 \times 45 \times 35 \mathrm{~mm}$ (length $\times$ width $\times$ height)] were filled with autoclaved soil (collected from IARI rice field) and two seedlings of identical genotype were sown per well. Seedlings were thinned to one healthy seedling in each well at 10 days. Five days later, plantlets were transferred to 18 well [ $80 \times 80 \times$ $70 \mathrm{~mm}$ (length $\times$ width $\times$ height)] trays containing $200 \mathrm{~g}$ soil in each well and each plantlet was inoculated with $200 \mathrm{~J} 2$ of M. graminicola. The experiment was carried out in a growth chamber at $28{ }^{\circ} \mathrm{C}, 60 \%$ humidity and $14: 10 \mathrm{~h}$ light: dark photoperiod (light level $-300 \mu \mathrm{mol}$ $\mathrm{m}^{-2} \mathrm{~s}^{-1}$ ). Plants were regularly watered to field capacity and fertilized with Yoshida's nutrient solution [22]. In order to avoid the secondary galling by RRKN, the experiment was terminated at $16 \mathrm{dpi}$ as M. graminicola completes its life cycle in 19 days at $24-30^{\circ} \mathrm{C}$ in well-drained soil $[3,5,6]$. Plants were carefully harvested, roots were washed in water, galls and other parameters were observed under the microscope. For each accession 12 plants were screened and the experiment was repeated at least twice.

Further, for stringent screening of 40 accessions, a higher nematode inoculum ( $2000 \mathrm{~J} 2 \mathrm{~s})$ was applied in PF-127 in Petri plates (150× $20 \mathrm{~mm}$ ) containing 50-55 seedlings of identical genotypes. Dishes were incubated, plantlets were harvested at $16 \mathrm{dpi}$ and nematode infection potential was assessed as described above.

\section{Genome-wide association analysis}

The set of 272 rice accessions were genotyped using in-house developed "OsSNPnks" 50K genic Affymetrix chip [44] containing a total of 50,051 high-quality SNPs. GWAS was performed with the rice accessions based on five important diverse nematode phenotypic traits such as number of galls, endoparasites, egg masses, eggs per egg mass and MF. A mixed linear model (MLM) was used to infer the association between each SNP and the phenotype, where markers and population structure (Q matrix) effects were fixed and the genotypic effect (K matrix) was random. The MLM was run in TASSEL v.5.2 (http://www.maizegenetics.net), where the additive genetic and residual variance components of the random factors were re-estimated for each SNP. TASSEL 5.2 computed the log likelihoods of the null and alternative models, and the effect of a SNP with its standard error. A p-value of $<0.0001$ (for traits gall, egg mass and MF) with minor allele frequency (MAF) value of $>5 \%$ was used as the threshold for significance analysis of marker-trait associations. A p-value of < 0.001 was used as the threshold for trait eggs per egg mass. To evaluate the genetic diversity across these diverse rice accessions, a phylogenetic tree was constructed by using the haplotype-based neighbour-joining algorithm, and the tree was visualized with FigTree v.1.4.0 [71].

STRUCTURE v.2.3.4 was employed to determine the genetic subpopulations among 272 accessions using a model-based Bayesian clustering method. Ten independent runs were performed setting the hypothetical number of expected populations $(\mathrm{K})$ range from 1-10. The data were processed with burn-in period and replication values of 50,000 each. The number of distinct subpopulations signify the optimal $\mathrm{K}$ value which was determined by estimating natural logarithm of the probability of fit (LnP(D)) obtained in the STRUCTURE output, whilst $\Delta K$ indicates the rate of change in $L n P(D)$ between successive $K$ values [72]. The Evanno plot was generated in Structure Harvester v.6.0 [73] to determine the peak $\Delta \mathrm{K}$ values.

Additionally, pairwise linkage disequilibrium (LD) between selective SNP markers was calculated using squared correlation coefficient $\left(\mathrm{r}^{2}\right)$ between two markers. The broad-sense heritability $\left(h^{2}\right)$ of phenotypic traits was estimated as $h^{2}=V_{G} /\left(V_{G}+V_{E}\right)$, where $V_{G}$ is genotypic variance and $V_{E}$ is residual variance. An additive ANOVA model was constructed to determine the phenotypic variation captured by the each set of SNPs.

\section{Candidate gene prediction}

Sequences flanking the SNP markers by $200 \mathrm{~kb}$ were selected via rice Pseudomolecule version 7 in the database Rice Genome Annotation Project (RGAP; http://rice.plantbiology.msu.edu/). In silico functional annotation of candidate genes was performed (BLASTp, BLAST2GO, gene ontology, Interpro and PFAM hits) to analyze the putative function of genes associated to RRKN or pathogen resistance with reference to previously published literature. Transposon or retrotransposon-related hits were excluded from the analysis.

\section{qRT-PCR analysis}

Page $12 / 22$ 
Expression analysis of the candidate genes was performed on the uninfected and infected root samples of Pusa 1121 at $7 \mathrm{dpi}$ (J2s inoculated in PF-127 medium as described above). Total RNA was extracted from the snap frozen (in liquid nitrogen) whole root systems using NucleoSpin total RNA kit (Macherey-Nagel, Germany) by following the manufacturer's protocol. RNA quantity and quality were assessed in Nanodrop ND-1000 spectrophotometer (Thermo Fisher Scientific). First-strand cDNA was synthesized from the total RNA using a SuperScript VILO cDNA synthesis kit (Invitrogen) by following the manufacturer's instructions. Samples were analyzed by qRT-PCR using SYBR Green Supermix kit (Eurogentec) in a Realplex ${ }^{2}$ thermal cycler (Eppendorf). To quantify the expression level of candidate genes, specific gene primers were used (Supplementary Table S4). cDNA matching 18S rRNA gene of O. sativa was amplified as a reference for constitutive expression using primers listed in Supplementary Table S4. Reaction mixture (10 $\mu$ l) for each sample consisted of $5 \mu$ SYBR Green PCR Master mix (Eurogentec), $750 \mathrm{nM}$ of each primer and $1.5 \mathrm{ng}$ cDNA. qRT-PCR cycling conditions and melt curve program were followed as previously described $[36,37]$. At least three biological and three technical replicates were used for each sample. Cycle threshold (Ct) values were imported from Realplex ${ }^{2}$ software (Eppendorf). Fold change in expression of candidate gene was determined via augmented comparative Ct method [74].

\section{Statistical analysis}

Data of the bioassay experiments were normalized using generalized linear model and subjected to two-way analysis of variance (ANOVA) in SAS software (version 14.1). Relative gall numbers, egg masses, MF etc. in different accessions were compared via post-hoc Tukey's honest significant difference test (HSD) at $\mathrm{P}<0.01$. For qRT-PCR data, significant differential expression of candidate genes between uninfected and infected plants was compared by post-hoc Tukey's HSD test $(P<0.01)$.

\section{Abbreviations}

GWAS:Genome-wide association mapping; SNP:Single nucleotide polymorphism; QTL:Quantitative trait loci; RRKN:Rice root-knot nematode; MLM:Mixed linear model; MAF:Minor allele frequency; TF:Transcription factor; MF:Multiplication factor; qRT-PCR:Quantitative real time PCR; LOC:Locus identifier

\section{Declarations}

\section{Ethics approval and consent to participate}

Not applicable on the manuscript.

\section{Consent for publication}

Not applicable on the manuscript.

\section{Availability of data and materials}

The data sets supporting this article are included in the article and in the additional files.

\section{Competing Interests}

The authors declare that they have no competing interests.

\section{Acknowledgements/Funding}

Present research was supported by the grants from IARI Outreach Project (IARI:ORP:NEM:09:04) and Department of Biotechnology, Ministry of Science and Technology (BT/PR18924/COE/34/48/2017).

\section{Authors' contributions}

AH performed all the experiments. TKD analyzed the data and wrote the manuscript. NS, VR and NKS helped in analyzing the data and provided the genetic material. UR conceived the study and edited the manuscript. All authors have approved the final manuscript.

\section{References}

1. Butardo Jr VM, Sreenivasulu N. Tailoring grain storage reserves for a healthier rice diet and its comparative status with other cereals. Int Rev Cell Mol Bio.2016;323:31-70.

2. De Waele D, Elsen A. Challenges in tropical plant nematology. Annu Rev Phytopathol. 2007;45:457-85. 
3. Dutta TK, Ganguly AK, Gaur HS. Global status of rice root-knot nematode, Meloidogyne graminicola. Afr J Microbiol Res. 2012;6:601621.

4. Dutta TK, Lovegrove A, Gaur HS, Curtis RH. Differential immunoreactivity of the root-knot nematodes, Meloidogyne graminicola and Meloidogyne incognita to polyclonal and monoclonal antibodies and identification of antigens through proteomics approach. Afr $\mathrm{J}$ Microbiol Res. 2014;8:1245-54.

5. Kyndt T, Fernandez D, Gheysen G. Plant-parasitic nematode infection in rice: molecular and cellular insights. Annu Rev Phytopathol. 2014;52:7.1-7.19.

6. Mantelin S, Bellafiore S, Kyndt T. Meloidogyne graminicola: a major threat to rice agriculture. Mol Plant Pathol.2017;18:3-15.

7. Lawilao JG, Kumar A, De Waele D. QTL mapping for resistance to and tolerance for the rice root-knot nematode, Meloidogyne graminicola. BMC Genet.2018;19:53.

8. Lawilao JG, Swamy BM, Kumar A, Cabasan MTN, De Waele D. Mapping quantitative trait loci of Meloidogyne graminicola resistance and tolerance in a recombinant inbred line population of Oryza glaberrima $\times$ sativa. Nematology2019;21:401-17.

9. Cabasan MTN, Kumar A, De Waele D. Evaluation of resistance and tolerance of rice genotypes from crosses of Oryza glaberrima and sativa to the rice root-knot nematode, Meloidogyne graminicola. Trop Plant Pathol.2018;43:230-41.

10. Jones MP, Dingkuhn M, Aluko GK, Semon M. Interspecific Oryza sativa $\times$ O. glaberrima Steud. progenies in upland rice improvement. Euphytica 1997;92:237-46.

11. Plowright RA, Coyne DL, Nash P, Jones MP. Resistance to the rice nematodes Heterodera sacchari, Meloidogyne graminicola and incognita in Oryza glaberrima and O. glaberrima $\times$ O. sativa interspecific hybrids. Nematology 1999;1:745-51.

12. Shrestha R, Uzzo F, Wilson MJ, Price AH. Physiological and genetic mapping study of tolerance to root-knot nematode in rice. New Phytol. 2007;176:665-72.

13. Jena M, Mohapatra SL, Pansa RS, Mohanty SK, Thatoi HN, Sahu SC. Genetic loci associated with root-knot nematode resistance in rice cv. Ramakrishna. Oryza 2013;50:132-9.

14. Bush WS, Moore JH. Genome-wide association studies. PLoS Comput Biol.2012;8:e1002822.

15. Myles S, Peiffer J, Brown PJ, Ersoz ES, Zhang Z, Costich DE, Buckler ES. Association mapping: critical considerations shift from genotyping to experimental design. Plant Cell2009;21:2194-202.

16. Riedelsheimer C, Lisec J, Czedik-Eysenberg A, Sulpice R, Flis A, Grieder C, et al. Genome-wide association mapping of leaf metabolic profiles for dissecting complex traits in maize. Proc Natl Acad Sci USA 2012;109:8872-7.

17. Wang S, Wong D, Forrest K, Allen A, Chao S, Huang BE, et al. Characterization of polyploid wheat genomic diversity using a highdensity 90000 single nucleotide polymorphism array. Plant Biotech J.2014;12:787-96.

18. Anwer MA, Anjam MS, Shah SJ, Hasan MS, Naz AA, Grundler FM, Siddique S. Genome-wide association study uncovers a novel QTL allele of AtS40-3 that affects the sex ratio of cyst nematodes in Arabidopsis. J Exp Bot.2018;69:1805-14.

19. Warmerdam S, Sterken MG, van Schaik C, Oortwijn ME, Sukarta OC, Lozano-Torres JL, et al. Genome-wide association mapping of the architecture of susceptibility to the root-knot nematode Meloidogyne incognita in Arabidopsis thaliana. New Phytol.2018;218:724-37.

20. Pariyar SR, Dababat AA, Sannemann W, Erginbas-Orakci G, Elashry A, Siddique S, et al. Genome-wide association study in wheat identifies resistance to the cereal cyst nematode Heterodera filipjevi. Phytopathology2016;106:1128-38.

21. Zhang H, Li C, Davis EL, Wang J, Griffin JD, Kofsky J, Song BH. Genome-wide association study of resistance to soybean cyst nematode (Heterodera glycines) HG Type 2.5.7 in wild soybean (Glycine soja). Front Plant Sci.2016;7:1214.

22. Dimkpa SON, Lahari Z, Shrestha R, Douglas A, Gheysen G, Price AH. A genome-wide association study of a global rice panel reveals resistance in Oryza sativa to root-knot nematodes. J Exp Bot. 2016;67:1191-200.

23. Singh B, Singh N, Mishra S, Tripathi K, Singh BP, Rai V, et al. Morphological and molecular data reveal three distinct populations of Indian wild rice Oryza rufipogon species complex. Front Plant Sci. 2018;9:123.

24. Tripathy K, Singh B, Singh N, Rai V, Misra G, Singh NK. A database of wild rice germplasm of Oryza rufipogon species complex from different agro-climatic zones of India. Database 2018;DOI: 1093/database/bay058.

25. Mather KA, Caicedo AL, Polato NR, Olsen KM, McCouch S, Purugganan MD. The extent of linkage disequilibrium in rice (Oryza sativa). Genetics2007;177:2223-32.

26. Rakshit S, Rakshit A, Matsumura H, Takahashi Y, Hasegawa Y, Ito A, et al. Large-scale DNA polymorphism study of Oryza sativa and rufipogon reveals the origin and divergence of Asian rice. Theor Appl Genet.2007;114:731-743. 
27. McNally KL, Childs KL, Bohnert R, Davidson RM, Zhao K, Ulat VJ, et al. Genome wide SNP variation reveals relationships among landraces and modern varieties of rice. Proc Natl Acad Sci USA 2009;106:12273-78.

28. Zhao K, Tung CW, Eizenga GC, Wright MH, Ali ML, Price AH, et al. Genome-wide association mapping reveals rich genetic architecture of complex traits in Oryza sativa. Nat 2011;2:467-75.

29. Kim H, Jung J, Singh N, Greenberg A, Doyle JJ, Tyagi W et al. Population dynamics among six major groups of the Oryza rufipogon species complex, wild relative of cultivated Asian rice. Rice 2016;9:56.

30. Sun CQ, Wang XK, Li ZC, et al. Comparison of the genetic diversity of common wild rice (Oryza rufipogon) and cultivated rice (O. sativa L.) using RFLP markers. Theor Appl Genet. 2001;102:157-62.

31. Brar DS. Utilization of wild species of genus Oryza in rice improvement. In: Monograph on Genus Oryza. Science Publishers: Enfield, $\mathrm{NH}, 2003$;pp. 283-309.

32. Khush GS. Origin, dispersal, cultivation and variation of rice. Plant Mol Biol. 1997;35:25-34.

33. Tanksley SD, McCouch, SR. Seed banks and molecular maps: unlocking genetic potential from the wild. Science 1997;277:1063-66.

34. Sanchez PL, Wing RA, Brar DS. The wild relative of rice: genomes and genomics. In: Genetics and Genomics of Rice. Springer, New York, 2013;pp. 9-25.

35. Londo JP, Chiang Y-C, Hung, K-H, Chiang T-Y, Schaal BA. Phylogeography of Asian wild rice, Oryza rufipogon, reveals multiple independent domestications of cultivated rice, Oryza sativa. Proc Natl Acad Sci USA 2006;103:9578-83.

36. Kumari C, Dutta TK, Banakar P, Rao U. Comparing the defence related gene expression changes upon root-knot nematode attack in susceptible versus resistant cultivars of rice. Sci Rep. 2016;6:22846.

37. Kumari C, Dutta TK, Gahoi S, Rao U. An insight into the expression profile of defence-related genes in compatible and incompatible Oryza sativa-Meloidogyne graminicolalndian J Genet PI Br. 2017;77:42-50.

38. Lahari Z, Ribeiro A, Talukdar P, Martin B, Heidari Z, Gheysen G, Price AH, Shrestha R. QTL-seq reveals a major root-knot nematode resistance locus on chromosome 11 in rice (Oryza sativa). Euphytica2019;215:117.

39. Pritchard JK, Stephens M, Donnelly P. Inference of population structure using multilocus genotype data. Genetics 2000;155:945-59.

40. Banaticla-Hilario MCN, McNally KL, van den Berg RG, Hamilton NRS. Crossability patterns within and among Oryza series Sativae species from Asia and Australia. Genet Resour Crop Ev. 2013;60:1899-1914.

41. Civán P, Craig H, Cox CJ, Brown TA. Three geographically separate domestications of Asian rice. Nat Plants 2015;1:15164.

42. Chen LJ, Lee DS, Song ZP, Suh HS, Lu BR. Gene flow from cultivated rice (Oryza sativa) to its weedy and wild relatives. Ann Bot. 2004;93:67-73.

43. Zhou H-F, Zheng X-M, Wei R-X, Second G, Vaughan DA, Ge S. Contrasting population genetic structure and gene flow between Oryza rufipogon and Oryza nivara. Theor Appl Genet. 2008;117:1181-9.

44. Singh N, Jayaswal PK, Panda K, Mandal P, Kumar V, Singh B, et al. Single-copy gene based 50 K SNP chip for genetic studies and molecular breeding in rice. Sci Rep.2015;5:11600.

45. Slatkin M. Isolation by distance in equilibrium and non-equilibrium populations. Evolution 1993;47:264-79.

46. Warmerdam S, Sterken MG, van Schaik C, Oortwijn ME, Lozano-Torres JL, Bakker J, et al. Mediator of tolerance to abiotic stress ERF6 regulates susceptibility of Arabidopsis to Meloidogyne incognita. Mol Plant Pathol. 2019;20:137-52.

47. Huang GZ, Dong RH, Allen R, Davis EL, Baum TJ, Hussey RS. A root-knot nematode secretory peptide functions as a ligand for a plant transcription factor. Mol Plant-Microbe Interact. 2006;19:463-70.

48. Mayrose M, Ekengren SK, Melech-Bonfil SHIRI, Martin GB, Sessa G. A novel link between tomato GRAS genes, plant disease resistance and mechanical stress response. Mol Plant Pathol. 2006;7:593-604.

49. Lim CW, Baek W, Lim S, Han SW, Lee SC. Expression and functional roles of the pepper pathogen-induced bZIP Transcription factor CabZIP2 in enhanced disease resistance to bacterial pathogen infection. Mol Plant-Microbe Interact.2015;28:825-33.

50. Tsuda K, Somssich IE. Transcriptional networks in plant immunity. New Phytol.2015;206:932-47.

51. Li X, Fan S, Hu W, Liu G, Wei Y, He C, Shi H. Two cassava Basic Leucine Zipper (bZIP) transcription factors (MebZIP3 and MebZIP5) confer disease resistance against cassava bacterial blight. Front Plant Sci. 2017;8:2110.

52. Bouzroud S, Gouiaa S, Hu N, Bernadac A, Mila I, Bendaou N, et al. Auxin response factors (ARFs) are potential mediators of auxin action in tomato response to biotic and abiotic stress (Solanum lycopersicum). PloS One 2018;13:e0193517.

53. Zhang $\mathrm{H}$, Teng W, Liang J, Liu X, Zhang H, Zhang Z, Zheng X. MADS1, a novel MADS-box protein, is involved in the response of Nicotiana benthamiana to bacterial harpin ${ }_{\text {Xoo. }}$ J Exp Bot. 2015;67:131-41.

Page $15 / 22$ 
54. Zhang YL, Zhang CL, Wang GL, Wang YX, Qi CH, Zhao Q, et al. The R2R3 MYB transcription factor MdMYB30 modulates plant resistance against pathogens by regulating cuticular wax biosynthesis. BMC Plant Biol.2019;19:362.

55. Milligan SB, Bodeau J, Yaghoobi J, Kaloshian I, Zabel P, Williamson VM. The root knot nematode resistance gene Mi from tomato is a member of the leucine zipper, nucleotide binding, leucine-rich repeat family of plant genes. Plant Cell1998;10:1307-19.

56. Monaghan J, Li X. The HEAT repeat protein ILITYHIA is required for plant immunity. Plant Cell Physiol.2010;51:742-53.

57. Krattinger SG, Keller B. Molecular genetics and evolution of disease resistance in cereals. New Phytol. 2016;212:320-32.

58. Juliana P, Singh RP, Singh PK, Poland JA, Bergstrom GC, Huerta-Espino J, et al. Genome-wide association mapping for resistance to leaf rust, stripe rust and tan spot in wheat reveals potential candidate genes. Theor Appl Genet.2018;131:1405-22.

59. Goff KE, Ramonell KM. The role and regulation of receptor-like kinases in plant defense. Gene Regul Syst Bio. 2007;1:167-75.

60. Zhou B, Mural RV, Chen X, Oates ME, Connor RA, Martin GB, et al. A subset of ubiquitin-conjugating enzymes is essential for plant immunity. Plant Physiol. 2017;173:1371-90.

61. Lee WY, Hong JK, Kim CY, Chun HJ, Park HC, Kim JC, et al. Over-expressed rice ADP-ribosylation factor 1 (RARF1) induces pathogenesis-related genes and pathogen resistance in tobacco plants. Physiol Plantarum2003;119:573-81.

62. Li D, Liu H, Zhang H, Wang X, Song F. OsBIRH1, a DEAD-box RNA helicase with functions in modulating defence responses against pathogen infection and oxidative stress. J Exp Bot.2008;59:2133-46.

63. Ono E, Wong HL, Kawasaki T, Hasegawa M, Kodama O, Shimamoto K. Essential role of the small GTPase Rac in disease resistance of rice. Proc Natl Acad Sci USA2001;98:759-64.

64. Moeder W, Yoshioka K, Klessig DF. Involvement of the small GTPase Rac in the defense responses of tobacco to pathogens. Mol Plant-Microbe Interact.2005;18:116-24.

65. Lorieux M, Reversat G, Diaz SXG, Denance C, Jouvenet N, Orieux Y, Bourger N, Bahoun AP, Ghesquière A. Linkage mapping of Has-10g, a resistance gene of African rice to the cyst nematode, Heterodera sacchari. Theor Appl Genet. 2003;4:691-6.

66. DeYoung BJ, Innes RW. Plant NBS-LRR proteins in pathogen sensing and host defense. Nat Immunol. 2006;7:1243-9.

67. Sano H, Seo S, Orudgev E, Youssefian S, Ishizuka K. Expression of the gene for a small GTP binding protein in transgenic tobacco elevates endogenous cytokinin levels, abnormally induces salicylic acid in response to wounding, and increases resistance to tobacco mosaic virus infection. Proc Natl Acad Sci USA 1994;91:10556-60.

68. Ye J, Zhong T, Zhang D, Ma C, Wang L, Yao L, et al. The Auxin-Regulated Protein ZmAuxRP1 Coordinates the Balance between Root Growth and Stalk Rot Disease Resistance in Maize. Mol Plant2019;12:360-73.

69. Kyndt T, Goverse A, Haegeman A, Warmerdam S, Wanjau C, Jahani M, et al. Redirection of auxin flow in Arabidopsis thaliana roots after infection by root-knot nematodes. J Exp Bot.2016;67:4559-70.

70. Dutta TK, Powers SJ, Kerry BR, Gaur HS, Curtis RHC. Comparison of host recognition, invasion, development and reproduction of Meloidogyne graminicola and incognita on rice and tomato. Nematology 2011;13:509-20.

71. Singh N, Singh B, Rai V, Sidhu S, Singh AK, Singh NK (2017) Evolutionary insights based on SNP haplotypes of red pericarp, grain size and starch synthase genes in wild and cultivated rice. Front Plant Sci8:972.

72. Evanno G, Regnaut S, Goudet J (2005) Detecting the number of clusters of individuals using the software STRUCTURE: a simulation study. Mol Ecol14:2611-2620.

73. Earl DA (2012) STRUCTURE HARVESTER: a website and program for visualizing STRUCTURE output and implementing the Evanno method. Conserv Genet Resour4:359-361.

74. Livak KJ, Schmittgen TD (2001) Analysis of relative gene expression data using real-time quantitative PCR and the 2(-Delta Delta $\mathrm{C}(\mathrm{T})$ ) Method. Methods 25:402-408.

\section{Figures}



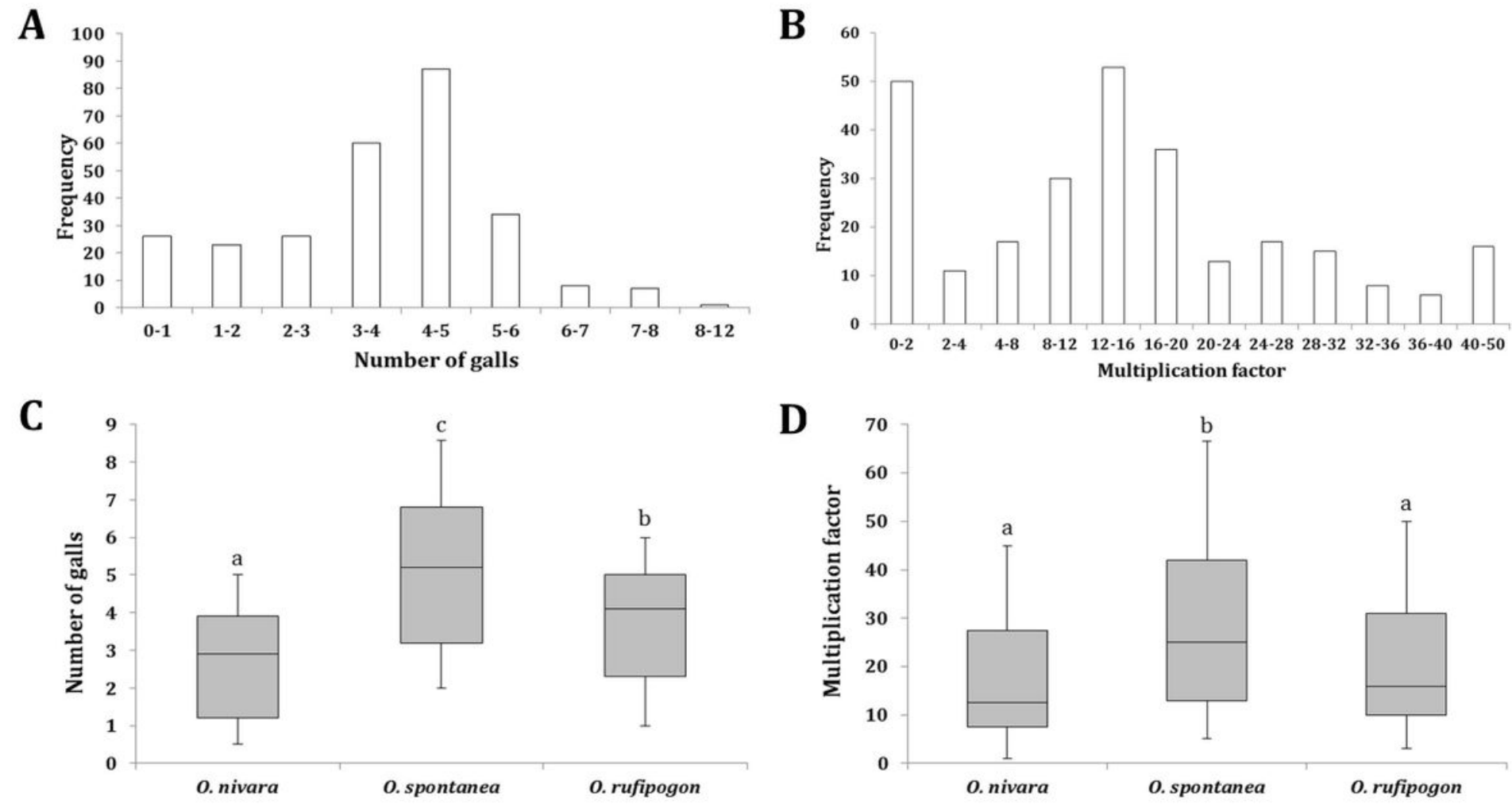

\section{Figure 1}

Host response of 272 rice accessions to M. graminicola infection at 16 dpi (inoculum level - $30 \mathrm{~J} 2 \mathrm{~s}$ per plant) in PF-127 medium. Frequency distribution of gall numbers $(A)$ and nematode multiplication factor $(B)$ in 272 genotypes. Box plot of relative gall numbers (C) and multiplication factor (D) across the different taxonomic groups of wild rice, namely O. nivara, O. rufipogon and O. spontanea. Box plots with the same letters are not significantly different $(P>0.01$, Tukey's HSD test; $n>30)$. 

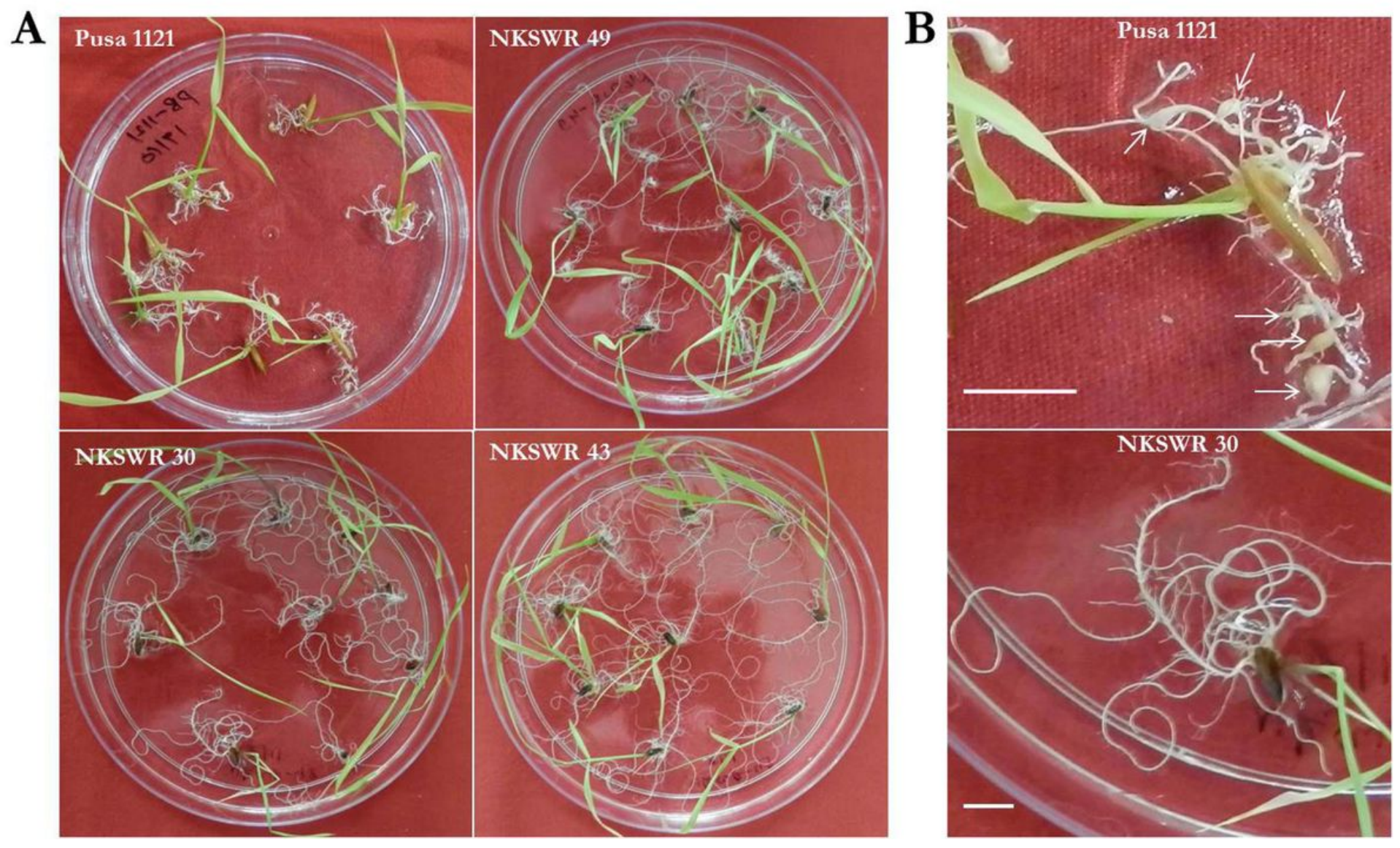

\section{Figure 2}

RRKN infected plantlets of selective accessions in Petri dishes containing PF-127 medium at $16 \mathrm{dpi}$ (inoculum level $-30 \mathrm{~J} 2 \mathrm{~s}$ per plant). (A) The susceptible check Pusa 1121 had $7.88 \pm 0.44$ galls in each plantlet. A wild accession NKSWR 49 exhibited $7.25 \pm 0.88$ mean number of galls. By contrast, NKSWR 30 and NKSWR 43 showed zero and $0.38 \pm 0.18$ galls, respectively. (B) A magnified view shows typical hook-shaped galls (indicated as white arrows) in Pusa 1121 and no gall in NKSWR 30 . Scale bar $=1 \mathrm{~cm}$. 
A

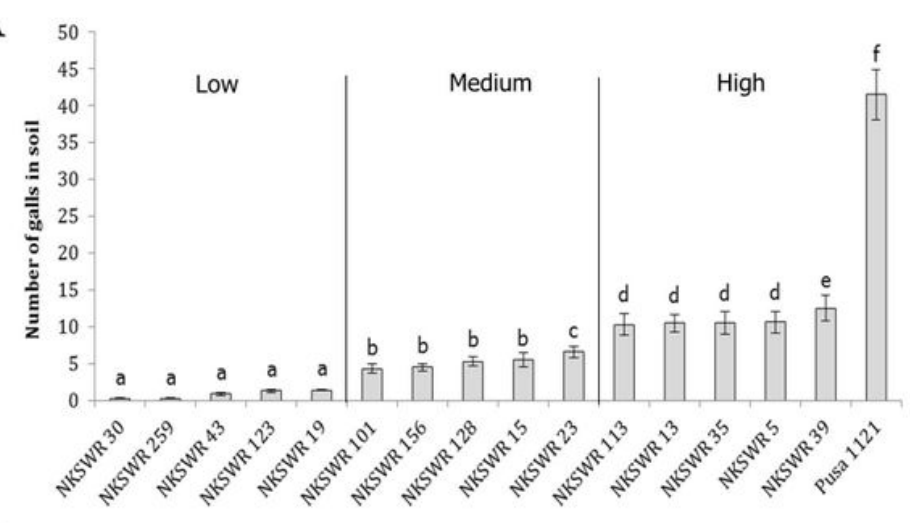

C

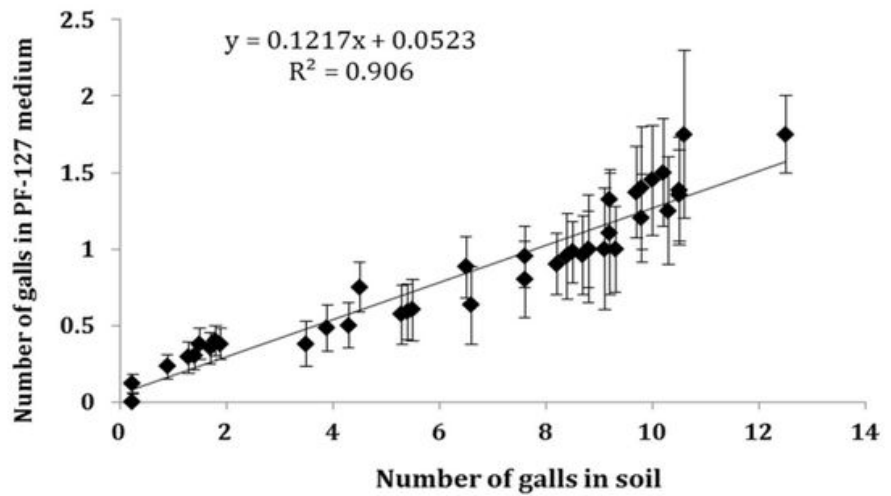

B

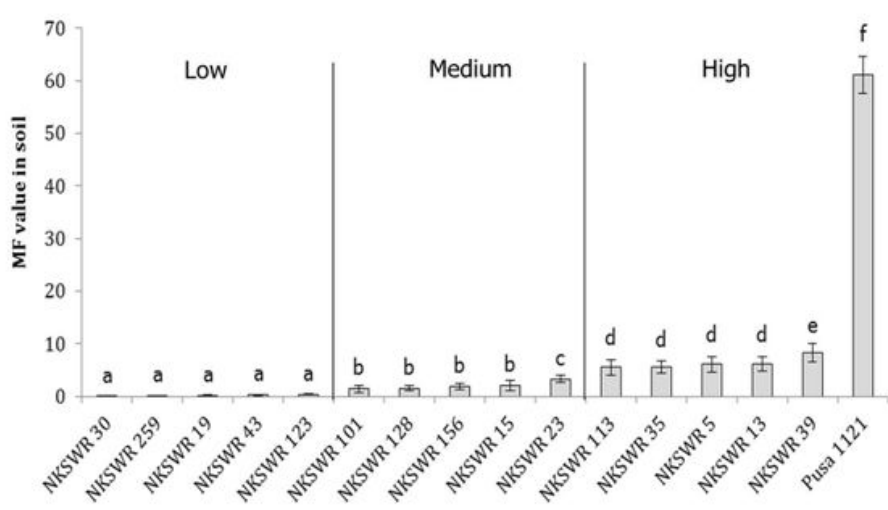

D

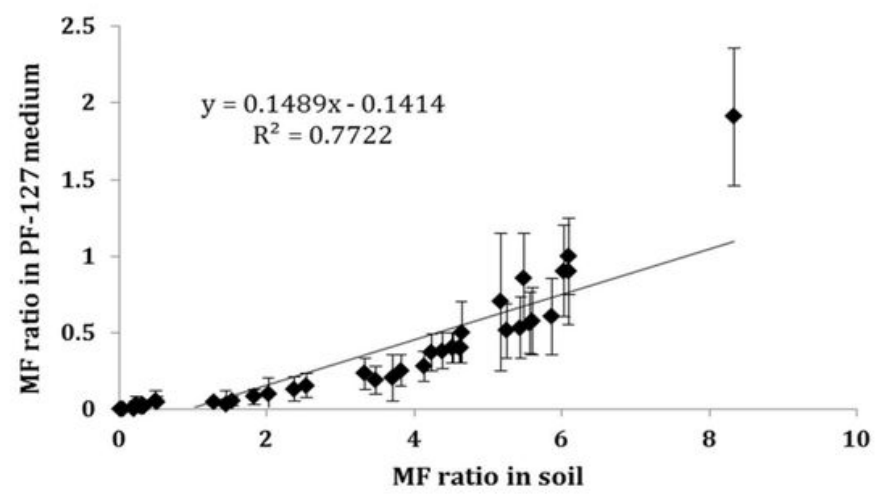

\section{Figure 3}

Host response of selective rice accessions to M. graminicola infection at $16 \mathrm{dpi}$ (inoculum level $-200 \mathrm{~J} 2 \mathrm{~s}$ per plant) in soil. Accessions were grouped into five each for low, medium and high incidence of gall numbers (A) and nematode multiplication factor (B). Data of reference genotype Pusa 1121 is shown. Each bar represents the mean \pm standard error $(n=12)$. Genotypes having different letters indicate significant difference at $P<0.01$, Tukey's HSD test. Plots of mean and standard error of gall numbers (C) and MF values (D) in all the 40 accessions in soil versus the screening of identical genotypes in PF-127 medium at $16 \mathrm{dpi}$.

A

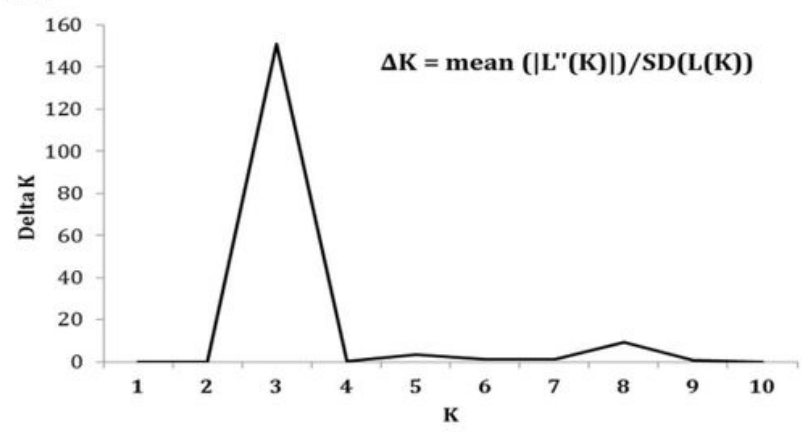

B

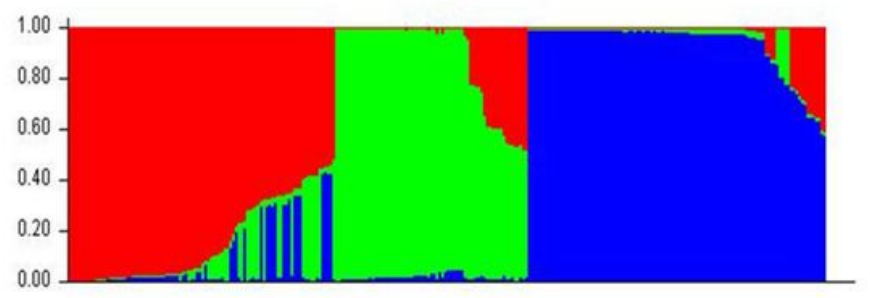

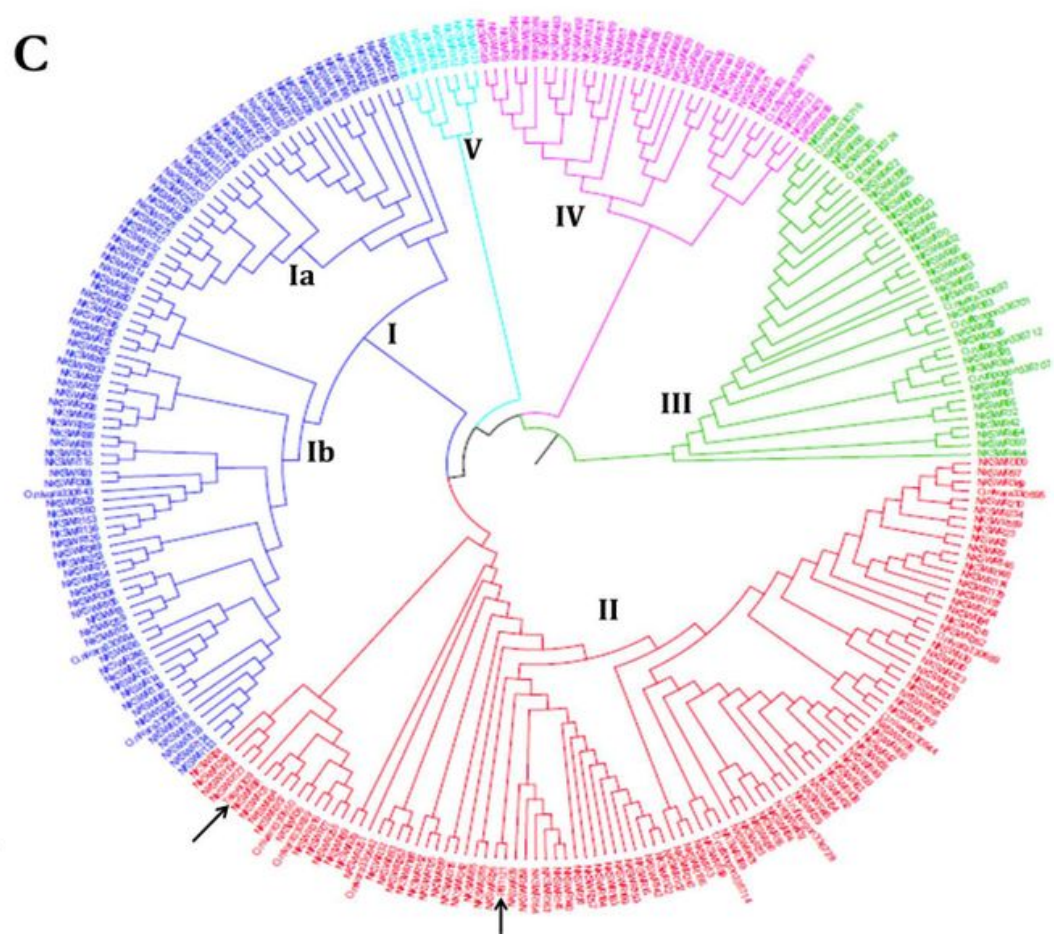

Figure 4 
Population structure and genetic diversity of 272 rice genotypes based on genome-wide 50K SNP chip. (A) Estimation of the number of populations $(K)$ in wild rice accessions using $\Delta K$ values. Three subgroups inferred from STRUCTURE analysis. (B) Distribution of rice accessions into three different populations. The colored region grouped the accessions in corresponding populations as red (Pro-Aus), green (Pro-Indica) and blue (Mid-Gangetic). X-and Y-axis indicate rice accessions and \% membership to a genetic group, respectively. (C) SNP haplotype-based neighbor-joining phylogenetic tree of 272 accessions shows wide genetic diversity among wild rice accessions. Five different clusters (highlighted as blue, red, green, magenta and sky blue) contained nine distinct sub-clusters. Reference genotypes (Taipei 309 and Pusa 1121) are indicated by arrows.
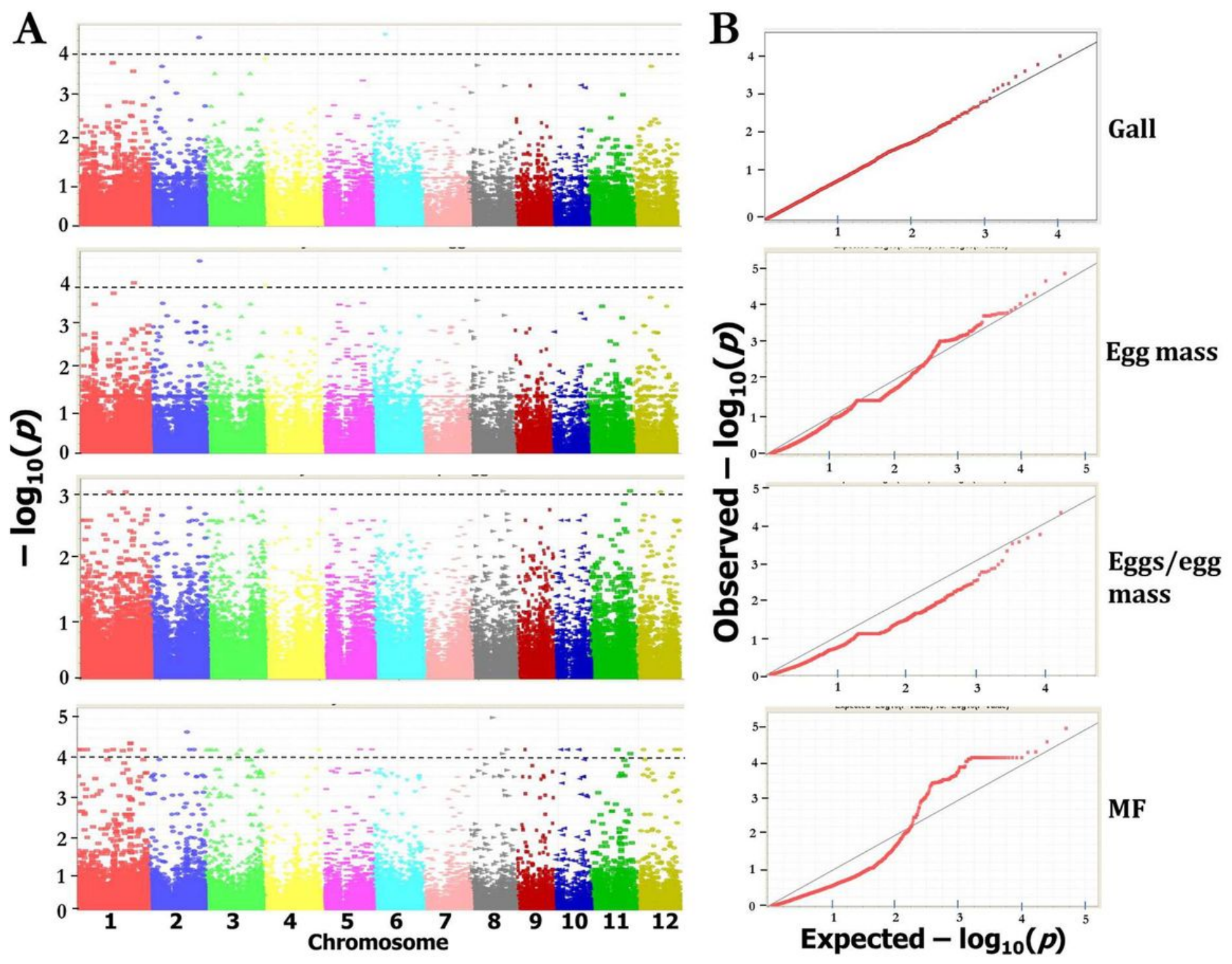

\section{Figure 5}

Genome-wide association analyses for RRKN resistance in wild rice. (A) Manhattan plots of P-values from the mixed linear model (MLM) for different traits such as numbers of galls, egg masses, eggs per egg mass and MF value. X-axis indicates the SNP location along the 12 chromosomes, $\mathrm{Y}$-axis is the - $\log 10$ (P-value). The dashed line represents the threshold defined by 1000 permutations of the association analysis. (B) Quantile-Quantile plots for different phenotypic traits with mixed model results. Dotted red line is the one-to-one line. X-axis represents expected $-\log 10(p)$ and $Y$-axis is observed $-\log 10(p)$ of each SNPs. 

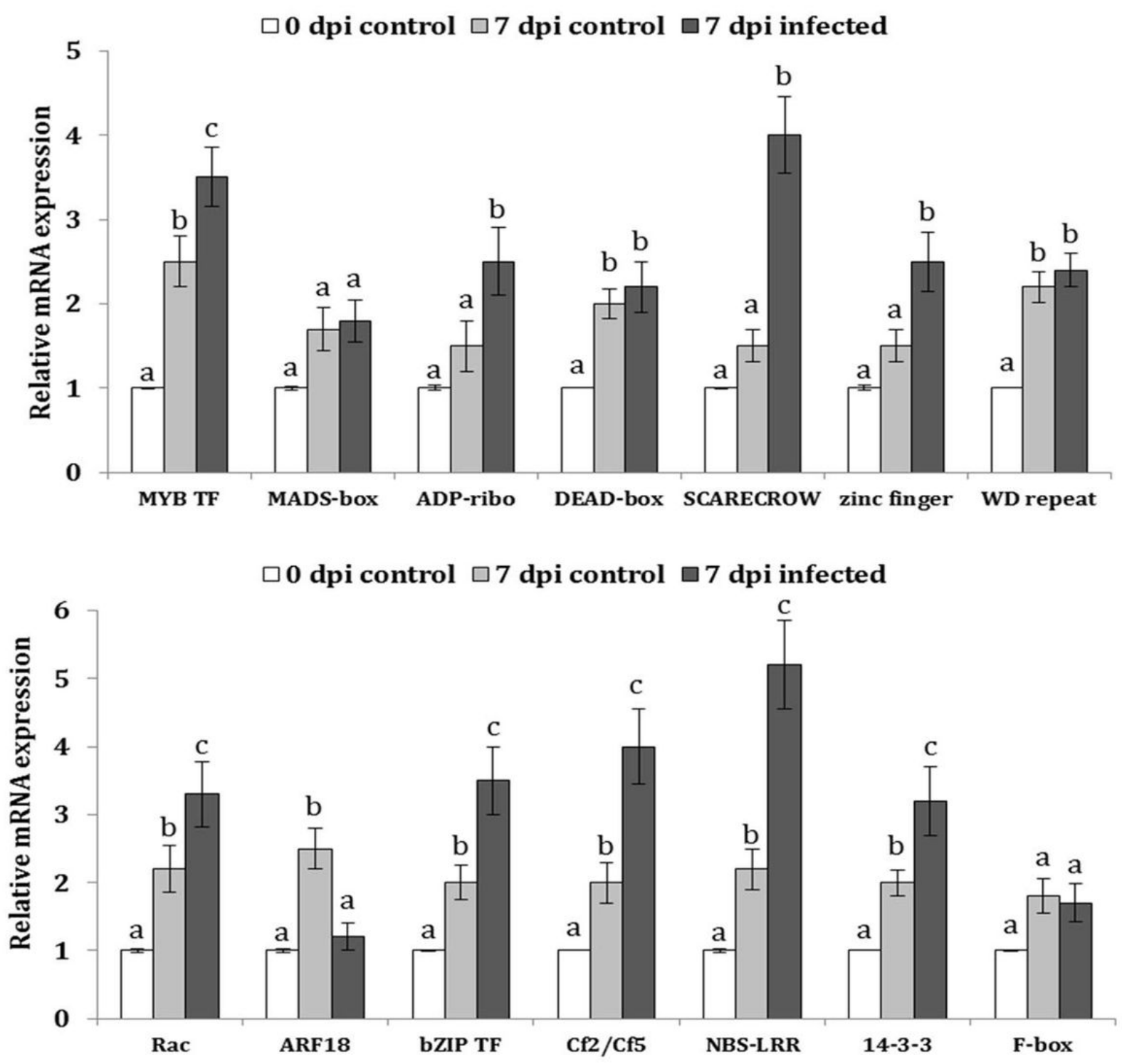

\section{Figure 6}

qRT-PCR-based differential expression patterns of 12 candidate genes in infected and uninfected root tissues of Pusa 1121 plants at 7 days post inoculation (dpi) with M. graminicola. Pusa 1121 was used as the reference cultivar. Data reflect gene expression levels in whole roots collected at the time of nematode inoculation ( $0 \mathrm{dpi}$ control), in whole roots at 7 days after mock inoculation ( $7 \mathrm{dpi}$ control) and at 7 days after nematode inoculation ( $7 \mathrm{dpi}$ infected). Gene expression levels were normalized using the internal reference gene of 0 . sativa, i.e. $18 \mathrm{~S}$ rRNA. Data are expressed as the fold change in expression. Bars represent mean expression levels \pm standard error from three biological and three technical replicates each containing a pool of ten plants. Different lower-case letters (within each gene) indicate statistical difference determined by ANOVA with post-hoc Tukey's HSD test, $\mathrm{P}<0.01$.

\section{Supplementary Files}

This is a list of supplementary files associated with this preprint. Click to download.

- GWASBMCTables1.pdf

- GWASBMCTables4.pdf

- GWASBMCFigureS1.pdf

- GWASBMCTableS3.pdf

- GWASBMCTables2.pdf 
Page 22/22 